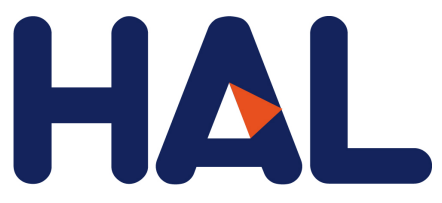

archives-ouvertes

\title{
Trace element analysis reveals bioaccumulation in the squid Gonatus fabricii from polar regions of the Atlantic Ocean
}

\author{
A. Lischka, T. Lacoue-Labarthe, P. Bustamante, U. Piatkowski, H.J.T. Hoving
}

\section{To cite this version:}

A. Lischka, T. Lacoue-Labarthe, P. Bustamante, U. Piatkowski, H.J.T. Hoving. Trace element analysis reveals bioaccumulation in the squid Gonatus fabricii from polar regions of the Atlantic Ocean. Environmental Pollution, Elsevier, 2020, 256, pp.113389. 10.1016/j.envpol.2019.113389 . hal-02412742

\section{HAL Id: hal-02412742 \\ https://hal.archives-ouvertes.fr/hal-02412742}

Submitted on 15 Dec 2019

HAL is a multi-disciplinary open access archive for the deposit and dissemination of scientific research documents, whether they are published or not. The documents may come from teaching and research institutions in France or abroad, or from public or private research centers.
L'archive ouverte pluridisciplinaire $\mathbf{H A L}$, est destinée au dépôt et à la diffusion de documents scientifiques de niveau recherche, publiés ou non, émanant des établissements d'enseignement et de recherche français ou étrangers, des laboratoires publics ou privés. 
Trace element analysis reveals bioaccumulation in the squid Gonatus fabricii from polar regions of the Atlantic Ocean

A. Lischka ${ }^{1 *}$, T. Lacoue-Labarthe ${ }^{2}$, P. Bustamante ${ }^{2}$, U. Piatkowski ${ }^{3}$, H. J. T. Hoving ${ }^{3}$

${ }^{1}$ AUT School of Science New Zealand, Auckland University of Technology, Private Bag 92006, 1142, Auckland, New Zealand

${ }^{2}$ Littoral Environnement et Sociétés (LIENSs), UMR 7266 CNRS-La Rochelle Université, 2 rue Olympe de Gouges, 17000 La Rochelle, France

${ }^{3}$ GEOMAR, Helmholtz Centre for Ocean Research Kiel, Düsternbrooker Weg 20, 24105 Kiel, Germany

*corresponding author: alexandralischka90@gmail.com 
Abstract: The boreoatlantic gonate squid (Gonatus fabricii) represents important prey for top predators - such as marine mammals, seabirds and fish-and is also an efficient predator of crustaceans and fish. Gonatus fabricii is the most abundant cephalopod in the northern Atlantic and Arctic Ocean but the trace element accumulation of this ecologically important species is unknown. In this study, trace element concentrations ( $\mathrm{Ag}, \mathrm{As}, \mathrm{Cd}, \mathrm{Co}, \mathrm{Cr}, \mathrm{Cu}, \mathrm{Fe}, \mathrm{Hg}, \mathrm{Mn}, \mathrm{Ni}, \mathrm{Pb}, \mathrm{Se}$, and $\mathrm{Zn}$ ) were analysed from the mantle muscle and the digestive gland tissue of juveniles, adult females, and adult males that were captured south of Disko Island off West-Greenland. To assess the feeding habitat and trophic position of this species, stable isotopes of carbon $\left(\delta^{13} \mathrm{C}\right)$ and nitrogen $\left(\delta^{15} \mathrm{~N}\right)$ were measured in their muscle tissue. Mercury concentrations were positively correlated with size (mantle length) and trophic position. The $\mathrm{Hg} / \mathrm{Se}$ ratio was assessed because Se has been suggested to play a protective role against $\mathrm{Hg}$ toxicity and showed a molar surplus of Se relative to $\mathrm{Hg}$. Cadmium concentrations in the digestive gland were negatively correlated with size and trophic position $\left(\delta^{15} \mathrm{~N}\right)$, which suggested/reflected a dietary shift from Cd-rich crustaceans towards Cd-poor fish during ontogeny. This study provides trace element concentration data for G. fabricii from Greenlandic waters, which represents baseline data for a northern cephalopod species. Within West-Greenland waters, G. fabricii appear to be an important vector in the transfer of $\mathrm{Cd}$ for the Arctic pelagic food web.

Keywords: Cephalopods; biomonitoring; trace metals; northern Atlantic; Gonatidae; trophic position; stable isotopes 


\section{Introduction}

Trace elements — such as arsenic, cadmium, lead or mercury — have important implications for human health and are indicators for environmental pollution (Tchounwou et al., 2012). In the marine environment, most metals and metalloids occur naturally at low concentrations (Langston, 1990). However, their levels can be increased by natural phenomena (such as atmospheric deposition, soil erosion or volcanic activity (Boutron et al., 1994)) and by anthropogenic activities (such as mining, river discharges or industrial wastes (e.g., Gao and Chen, 2012; García et al., 2008).

The Arctic Ocean has been suggested to be particularly vulnerable to trace element contamination because it acts as a sink for various contaminants that are transported north through the atmosphere, rivers and oceanic currents (Barrie et al., 1992; McConnell and Edwards, 2008; Muir et al., 1992). Arctic marine mammals, fish and birds have been the focus of several trace element concentration studies and long-term biomonitoring programs (e.g., AMAP, 2018; Becker, 2000; Campbell et al., 2005; Dehn et al., 2006; Dietz et al., 1996; Macdonald and Sprague, 1988; Zauke et al., 1999). However, to the best of our knowledge, cephalopods have not been included in these previous studies, although they have been proposed as vectors of contaminants, particularly $\mathrm{Cd}$ and $\mathrm{Hg}$, to marine top predators (Bustamante et al., 1998a, 2006).

Indeed, cephalopods play a pivotal role in the Arctic marine ecosystem as both predators and prey (Nesis, 1965, 2001; Gardiner and Dick, 2010). Their distribution has been correlated to the occurrence of predators, such as toothed whales (Bjørke, 2001), the northern fulmar, Fulmarus glacialis (Savinov et al., 2003), and the Greenland halibut, Reinhardtius hippoglossoides (Orr and Bowering, 1997). The northern distribution ranges of some cephalopod species appear to have been expanded by warming Arctic waters (Gardiner and Dick, 2010, Gilly, 2005; Golikov et al., 2013). In addition, increased abundance can result in a shift in the predator's diet from fish to squid, changing the contaminant exposure accordingly (Dehn et al., 2006). Therefore, it is fundamentally important to consider cephalopods as a major vector in the trace element transfer along trophic food webs linking their trace element concentrations to their ecological role.

The boreoatlantic gonate squid Gonatus fabricii (Lichtenstein, 1818) is the most abundant squid in the northern Atlantic and Arctic Ocean (Kristensen, 1983; Nesis, 2001; Zumholz and Frandsen, 2006; Gardiner and Dick, 2010; Golikov et al., 2018) and represents the only squid species that spends its entire life cycle of around two years, in the Arctic Ocean (Golikov et al., 2018; Kristensen, 1984; Nesis, 1971). It shows a vertical distribution that covers a broad depth range, with early life stages 
occurring from the surface to about $1000 \mathrm{~m}$ depth, and more mature stages down to $3000 \mathrm{~m}$ (Kristensen, 1983, 1984; Nesis, 1965; Piatkowski and Wieland, 1993; Wiborg, 1982). This ontogenetic descent has also been inferred from variations in $\mathrm{Sr} / \mathrm{Ca}$ ratios in the statoliths of $G$. fabricii captured off West Greenland, which suggests a migration of adult squids into deeper and colder waters (Zumholz et al., 2007). The species is believed to spawn near the bottom of the continental slopes off West Greenland and northern Norway (Arkhipkin and Bjørke, 1999; Kristensen 1984) and spawned eggs are likely carried ('brooded') by the female in the water column as observed for the sister species G. onyx in the Pacific (Bjørke et al., 1997; Seibel et al 2005).

Gonatus fabricii plays an important role in the energy transfer from epipelagic to meso- and bathypelagic layers through its vertical migration (Gardiner and Dick, 2010; Kristensen, 1984). Although both juvenile and adult G. fabricii prey on macroplanktonic crustaceans (Kristensen, 1984; Nesis, 1965; Sennikov et al., 1989), their diet shifts during maturation from invertebrates (i.e., amphipods, copepods, euphausids, pteropods, and chaetognaths) to fish (e.g., capelin, Arctic cod, redfish, and lanternfish) and other cephalopods (Sennikov et al., 1989; Wiborg, 1984). In the Arctic marine food web, G. fabricii is a major prey item for seals, various cetaceans, seabirds, and deep-sea fishes (Gardiner and Dick, 2010). Sperm whales alone are estimated to consume 1.5 million tonnes of G. fabricii annually in the northern Atlantic (Bjørke, 2001). Squid prey that was estimated from cephalopod beaks in stomach contents of sperm whales that stranded along the coasts of the North Atlantic consisted of up to $99 \%$ of G. fabricii (Bjørke and Gjøsæter, 2004; Ijsseldijk et al., 2018; Martin and Clarke, 1986; Santos et al., 1999;). Narwhales, Monodon monoceros, observed in West Greenland waters during autumn almost exclusively fed on G. fabricii (Laidre and Heide-Jørgensen, 2005). Furthermore, G. fabricii plays an economic role because it is used as bait in Greenland's longline and trap fisheries (Frandsen and Wieland, 2004), which make up around $85 \%$ of Greenland's economic exports (Lund, 2018).

The overall aim of the present study was to assess the trace element accumulation and trophic position of G. fabricii within a polar region of the Atlantic Ocean. This was addressed through the following means:

- 1) the measurement of stable isotope values of carbon and nitrogen in muscle tissue to investigate shifts in the relative trophic position of G. fabricii during ontogeny;

- 2) the determination of trace element concentrations in the mantle muscle ( $>70 \%$ of the total mass of the squid) and the digestive gland (a key organ in the bioaccumulation and detoxification of 
contaminants; Penicaud et al. 2017) of juvenile and adult G. fabricii specimens;

- 3) the combination of trace element and stable isotope data to observe changes in trace element concentration in conjunction with shifts in diet and feeding habitat.

\section{Material and Methods}

\subsection{Sample collection}

Specimens of Gonatus fabricii were collected by the research vessel 'Paamiut' (Greenland Institute of Natural Resources) by midwater trawling in depths of 569-590 m, south of Disko Island off Western Greenland (69 $\left.23^{\prime} \mathrm{N}, 5^{\circ} 63^{\prime} \mathrm{W}\right)$ on 16 July 2005 (Fig 1). A total of 45 specimens were stored at $-40^{\circ} \mathrm{C}$, composed of 15 males (dorsal mantle length [DML]: 90-274 mm), 15 females (DML: 76$193 \mathrm{~mm}$ ), and 15 juveniles (DML: 30-56 mm).

\subsection{Stable isotope analysis}

Carbon and nitrogen stable isotopes were analysed from subsamples $(0.2-0.4 \mathrm{mg})$ of the freeze-dried mantle tissue with a continuous flow mass spectrometer (Delta V Plus with a Conflo IV interface, Thermo Scientific, Bremen, Germany) coupled to an elemental analyzer (Flash 2000, Thermo Scientific, Milan, Italy). Results are expressed in the $\delta$ unit notation as deviations from standards (Vienna Pee Dee Belemnite for $\delta^{13} \mathrm{C}$ and $\mathrm{N}_{2}$ in air for $\delta^{15} \mathrm{~N}$ ) following the formula: $\delta^{13} \mathrm{C}$ or $\delta^{15} \mathrm{~N}=$ $\left[\left(\mathrm{R}_{\text {sample }} / \mathrm{R}_{\text {standard }}\right)-1\right] \times 10^{3}$, where $\mathrm{R}$ is ${ }^{13} \mathrm{C} /{ }^{12} \mathrm{C}$ or ${ }^{15} \mathrm{~N} /{ }^{14} \mathrm{~N}$, respectively. The analytical precision, based on internal laboratory standards (acetanilide and peptone), was $<0.10 \%$ for $\delta^{13} \mathrm{C}$ and $<0.15 \%$ o for $\delta^{15} \mathrm{~N}$.

\subsection{Trace element analysis}

Prior to trace element analysis, tissue samples of digestive gland and mantle muscle were freeze-dried for 48 hours and homogenized. Water content ranged from $33.5-67.3 \%$ in the digestive gland and $72.9-89.4 \%$ in the mantle tissue. Sample aliquots ( 200 mg dry weight [dw]) were digested overnight 
in a 3:1 mixture of $65 \% \mathrm{HNO}_{3}$ (Merck, suprapur quality) and 37\% $\mathrm{HCl}$ (Merck, suprapur quality). This was followed by mineralization by heating the samples for $30 \mathrm{~min}$ in a Milestone microwave (maximum temperature of $105^{\circ} \mathrm{C}$ ). Trace element concentrations ( $\mathrm{Ag}, \mathrm{As}, \mathrm{Cd}, \mathrm{Co}, \mathrm{Cr}, \mathrm{Cu}, \mathrm{Fe}, \mathrm{Mn}$, $\mathrm{Ni}, \mathrm{Pb}, \mathrm{Se}$, and $\mathrm{Zn}$ ) were measured by inductively coupled plasma mass spectroscopy (ICP-MS) (Thermo Fisher Scientific X Series 2) and optical emission spectroscopy (OES) (Varian Vista-Pro) following Lucia et al. (2016). Procedural blanks and certified reference materials (CRM)—dogfish liver (DOLT-4, National Research Council, Canada), lobster hepatopancreas (TORT-3, NRCC), and clam muscle tissue (IAEA461, International Atomic Energy Agency, Austria) -were treated and analysed in the same way as the other samples. Recoveries of the elements ranged from 85-105\% $(\mathrm{n}=9)$. The detection limits for $\mathrm{Ag}, \mathrm{Cd}, \mathrm{Co}$, and $\mathrm{Pb}$ were $0.025 \mu \mathrm{g} \cdot \mathrm{g}^{-1}, \mathrm{Fe}$ and $\mathrm{Zn}$ were $5 \mu \mathrm{g} \cdot \mathrm{g}^{-1}, \mathrm{Cu}$ and Se were $0.125 \mu \mathrm{g} \cdot \mathrm{g}^{-1}$, and $\mathrm{Ni}$ was $0.05 \mu \mathrm{g} \cdot \mathrm{g}^{-1}$, based on $200 \mathrm{mg}$ of sample material diluted in a volume of $50 \mathrm{ml}$. Cadmium concentrations were only measured in the digestive gland of specimens in order to prevent storage diffusion effects (Lischka et al., in press; Bustamante et al., 2002; Francesconi et al., 1993).

Mercury concentrations were measured using an Advanced Mercury Analyser (ALTEC AMA 254, with a detection limit $>0.05 \mathrm{ng}$ ) on dried, homogenized digestive gland and mantle tissue (1-2 mg dw) as described in Bustamante et al. (2006). For every 10 samples, one standard sample of certified reference material DOLT 5 (Dogfish liver; NRCC) was analysed (recovery=109\%). The detection limit was $0.05 \mathrm{ng}$. Results for trace element concentrations are expressed in $\mu \mathrm{g} . \mathrm{g}^{-1} \mathrm{dw}$.

\subsection{Mercury:selenium interaction}

In order to assess $\mathrm{Hg}$ and $\mathrm{Se}$ ratios, measured concentrations were converted from $\mu \mathrm{g} \cdot \mathrm{g}^{-1} \mathrm{dw}$ into nmol.g $\mathrm{g}^{-1}$ using the molecular weight of 200.59 for $\mathrm{Hg}$ and 78.96 for Se. Ratios were assessed for both tissue types, as a $\mathrm{Hg}: \mathrm{Se}$ ratio $>1$ indicates an excess of $\mathrm{Hg}$ in relation to $\mathrm{Se}$ in the tissue (Cuvin-Aralar and Furness, 1991; Ralston et al., 2008).

\subsection{Statistical analysis}

Most statistical analyses were conducted with $\mathrm{R}$ version 3.3.3 (Ihaka and Gentleman, 1996). Prior to data analysis, values below the detection limit were replaced by the lowest measured value of the corresponding element multiplied by 0.5 . The samples were normalised and transformed using autoscaling, mean centred, and divided by the standard deviation. Principal component analysis (PCA) plots were produced to examine differences in overall trace element concentrations among tissue 
types and maturation stage, using the package 'ggbiplot' (Vu, 2011). Correlations among trace element concentrations in the two tissues were assessed using the R package 'corrgram' (Wright, 2012). Significance of the variable collinearity was tested using pairwise nonparametric Spearman correlations ('corr.test' function of the 'corrgram' package, Wright, 2012). Using the software MetaboAnalyst v2.0 (https://github.com/xia-lab/MetaboAnalystR), heatmaps were generated using Euclidean distance and Ward hierarchical clustering.

Analyses of covariance (ANCOVA) were performed in $\mathrm{R}$ to check if concentrations of the trace elements ( $\mathrm{Ag}, \mathrm{As}, \mathrm{Cd}, \mathrm{Hg}$, and $\mathrm{Pb}$ ) in the two tissues were influenced by size, stable isotope values, or sex. Prior to the statistical tests, trace element concentrations were z-transformed (Graf, 2004) and diagnostic plots were used to check for variance homogeneity and normality of the residues. Explanatory variables were added (in the following order: DML, $\delta^{15} \mathrm{~N}$, sex, $\delta^{13} \mathrm{C}$ ) to see if the feeding habitat had an effect once size was accounted for. Analysis of variance (ANOVA) was conducted to test if there was a relationship between stable isotope values and sex/maturity stage (female, male, juvenile).

\section{Results}

\subsection{Stable isotope values}

The $\delta^{13} \mathrm{C}$ were on average highest in mature males (-18.96\%o), followed by females $(-19.10 \%$ ), and juveniles (-20.60\%) (Table 1). The $\delta^{13} \mathrm{C}$ values showed a distinct grouping with maturity stage (ANOVA, F-value $=339.66, \mathrm{p}<0.001)$; Fig. 3). The $\delta^{15} \mathrm{~N}$ values were significantly higher in females (12.75-15.15\%o) and males (12.64-15.12\%o), compared to juveniles (8.59-9.64\%o) (ANOVA, Fvalue $=339.66, \mathrm{p}<0.001 ;$ Table 1, Fig. 3)

\subsection{Trace element concentrations}

Trace element concentrations in the digestive gland of mature Gonatus fabricii (females and males) followed the order $\mathrm{Cu}>\mathrm{Zn}>\mathrm{Fe}>\mathrm{Cd}>\mathrm{As}>\mathrm{Se}>\mathrm{Ag}>\mathrm{Ni}>\mathrm{Mn}>\mathrm{Co}>\mathrm{Cr}>\mathrm{Pb}>\mathrm{Hg}$. Those measured in juveniles were found in the following order: $\mathrm{Fe}>\mathrm{Zn}>\mathrm{Cd}>\mathrm{Cu}>\mathrm{As}>\mathrm{Se}>\mathrm{Ni}>\mathrm{Mn}>\mathrm{Cr}>\mathrm{Co}>\mathrm{Ag}>\mathrm{Pb}>\mathrm{Hg}$ (Table 1). Between matures and juveniles, juveniles showed higher concentrations of $\mathrm{Cd}, \mathrm{Co}, \mathrm{Cr}, \mathrm{Fe}$, $\mathrm{Mn}, \mathrm{Ni}, \mathrm{Pb}, \mathrm{Se}$, and $\mathrm{Zn}$ in the digestive gland, while mature specimens had the highest concentrations of $\mathrm{Ag}$ and $\mathrm{Cu}$ (Table 1, Fig. S1).

Trace element concentrations in the mantle muscle of mature individuals followed the order 
$\mathrm{Zn}>\mathrm{Cu}>\mathrm{As}>\mathrm{Fe}>\mathrm{Mn}>\mathrm{Se}>\mathrm{Ag}>\mathrm{Mn}>\mathrm{Ni}>\mathrm{Cr}>\mathrm{Hg}>\mathrm{Ag}>\mathrm{Co}>\mathrm{Pb}$. Those found in juveniles ranged in the following order: $\mathrm{Zn}>\mathrm{Fe}>\mathrm{Cu}>\mathrm{As}>\mathrm{Se}>\mathrm{Mn}>\mathrm{Ni}>\mathrm{Cr}>\mathrm{Co}>\mathrm{Pb}>\mathrm{Hg}>\mathrm{Ag}$. The mature specimens exhibited the highest concentrations of $\mathrm{As}$ and $\mathrm{Hg}$, with maximum concentrations measured in mantle tissue of males (Table 1, Fig. 2, Fig. S1). The PCA showed a distinction between tissue type and maturation stage (Fig. 2). The first axis of the PCA explained $45.6 \%$ of the variance, the second axis $27.6 \%$. Principle component (PC) 1 was mainly driven by $\mathrm{Cd}, \mathrm{Co}, \mathrm{Cr}, \mathrm{Fe}, \mathrm{Ni}, \mathrm{Pb}, \mathrm{Se}$, and $\mathrm{Zn}$, while PC 2 was mainly driven by $\mathrm{Ag}, \mathrm{Cd}, \mathrm{Co}$, and $\mathrm{Cu}$.

\subsection{Trace element correlations}

The concentrations of $\mathrm{Hg}$ and $\mathrm{Se}$ in the mantle tissue showed a negative correlation $(r=-0.60$, $p<0.001$ ). The molar ratio between $\mathrm{Hg}$ and $\mathrm{Se}$ in the digestive gland (mean=0.007) and the mantle tissue (mean=0.024) were well below one (Fig. 4a, b). A linear relationship between the $\mathrm{Hg}$ concentration and the molar ratio of $\mathrm{Hg}$ :Se in the mantle tissue was observed (Fig. $4 \mathrm{~b}$ ).

In the digestive gland tissue, $\mathrm{Zn}$ showed a positive correlation with $\mathrm{Cd}(r=0.37, p=0.01)$, while a negative relationship was found between $\mathrm{Zn}$ and $\mathrm{Cu}(r=-0.65, p<0.001)$. Chromium and $\mathrm{Ni}$ were positively correlated both in the digestive gland $(r=0.93, p<0.001)$ and mantle tissue $(r=0.90$, $p<0.001)$.

\subsection{Relationship between trace metal concentrations and stable isotopes}

ANCOVAs were performed to test which variables $\left(\delta^{15} \mathrm{~N}, \delta^{13} \mathrm{C}\right.$, size - or DML, and sex $)$ influence the concentrations of the elements $\mathrm{Ag}, \mathrm{As}, \mathrm{Cd}, \mathrm{Cu}, \mathrm{Hg}, \mathrm{Pb}$, and $\mathrm{Zn}$. Silver concentrations in both tissues were significantly influenced by $\delta^{15} \mathrm{~N}$, while the digestive gland was also affected by size (Table 2). Arsenic concentrations in both tissues showed a significant relationship with size and $\delta^{15} \mathrm{~N}$. Cadmium concentrations in the digestive gland showed a significant relationship with stable isotope values and sex. Copper concentrations in the digestive gland were influenced by size, stable isotope values, and sex, while concentrations in the mantle tissue were only significantly influenced by $\delta^{15} \mathrm{~N}$. Mercury concentrations in both tissues showed a significant relationship with size and $\delta^{15} \mathrm{~N}$; however, $\mathrm{Hg}$ concentrations were higher in the mantle tissue and showed an additional relationship with sex. Both tissues showed significant relationships between $\mathrm{Pb}$ concentration with size and $\delta^{13} \mathrm{C}$ (Table 2). Zinc concentrations were significantly correlated with size and sex in both tissues, while the digestive gland showed an additional relationship with $\delta^{15} \mathrm{~N}$. 


\section{Discussion}

The trace element concentrations in deep-sea cephalopods, especially from high latitudes, are highly relevant in terms of bioaccumulation, due to the pivotal role that cephalopods play in marine ecosystems. The boreoatlantic gonate squid, Gonatus fabricii, is the most abundant cephalopod in the northern Atlantic Ocean and a key element in the oceanic food web and hence highly relevant for the understanding of Arctic open-ocean ecology. We herein assess trace element concentrations in this cephalopod species from Greenland waters, which helps unravelling the bioaccumulation patterns within the sensitive Arctic ecosystem.

\subsection{Stable Isotopes}

Stable isotopic signatures have been used for cephalopods to assess their trophic ecology (through $\delta^{15} \mathrm{~N}$ ) and the habitat use (through $\delta^{13} \mathrm{C}$, Cherel and Hobson, 2005; Hobson, 1999). Nitrogen stable isotope values $\left(\delta^{15} \mathrm{~N}\right)$ are considered to be directly related to diet and are therefore used as an indicator of trophic position (DeNiro and Epstein, 1978, 1981; Graham et al., 2010). Enriched $\delta^{15} \mathrm{~N}$ values indicate a higher trophic position of adult G. fabricii relative to juveniles (Fig. 4). This phenomenon has been well documented in fish (e.g., Chouvelon et al., 2014; Galván-Magaña et al., 2012), while fewer studies have focused on squid species (e.g., Chouvelon et al., 2011; Lischka et al., 2018; Merten et al., 2017). We found an increase in the $\delta^{15} \mathrm{~N}$ values associated with size, which was attributed to a shift in the trophic regime (i.e. predating prey of higher trophic levels; Kristensen, 1984), which is concomitant with a significant increase of the $\delta^{13} \mathrm{C}$ values from immature to mature G. fabricii (Fig. $3)$.

Our distinct separation in the $\delta^{13} \mathrm{C}$ values of mature individuals and juveniles indicates an ontogenetic shift in habitat of G. fabricii (Fig 3). The differences found in different G. fabricii life stages for $\delta^{13} \mathrm{C}$ are likely related to ontogenetic migration where older and larger specimens live deeper than juveniles (Kristensen, 1983; Nesis, 1965; Sennikov et al., 1989). Both these signatures are consistent with the known change in feeding habits as a result of ontogenetic migration with larger adults living in deeper waters (Nesis, 1965; Kristensen, 1983; Sennikov et al., 1989). Our results are consistent with the ontogenetic changes previously reported from stable isotope signatures in the beaks of G. fabricii (DML13-257 mm) captured off Greenland and in the Barents Sea (Golikov et al., 2018), and in elemental signatures in the statoliths (Zumholz et al., 2007). 


\subsection{Trace element concentrations}

\subsubsection{Cadmium}

Compared to other taxa, cephalopods have a high capacity to accumulate toxic $\mathrm{Cd}$ in elevated concentrations in the digestive gland (Penicaud et al., 2017). Gonatus fabricii shows intermediate Cd concentrations, relative to the low levels found in the Loliginidae (Bustamante et al., 2002) and the concentrations reported for oceanic Ommastrephidae (Gerpe et al., 2000; Lischka et al., 2018, 2019; Table 3). Although unusually high Cd concentrations have been previously reported in the subpolar waters of both hemispheres (Bustamante et al., 1998ab, 2003; MacDonald and Sprague 1988; Petri and Zauke 1993; Ritterhoff and Zauke, 1997), G. fabricii does not appear to bioaccumulate this trace element in those extreme concentrations. Physiological factors are likely responsible for this decreased Cd bioaccumulation relative to the Ommastrephidae. For example, the digestive gland of Ommastrephids and Sepiidae, contrasting to Loliginids, possesses a lysosomal system with specific cells ('boules' structures) that are thought to be involved in the storage of large amounts of $\mathrm{Cd}$ (Penicaud et al., 2017). The detoxification mechanisms in G. fabricii are not fully understood and future studies should focus on this aspect of their physiology.

The Cd concentrations found in G. fabricii individuals show a strong correlation with life stage (Table 1,2; Fig 2). Juveniles had higher Cd concentrations than adults, which could be linked to the ontogenetic change in diet that was revealed through the $\delta^{15} \mathrm{~N}$ values discussed above (Table 1). Indeed, diet has been suggested as the main source for $\mathrm{Cd}$ accumulation in cephalopods (Penicaud et al., 2017). Juvenile G. fabricii have been reported to feed mainly on crustaceans in epipelagic waters, whereas adult specimens predominantly feed on deeper meso- and bathypelagic fishes (Bjørke and Gjøsæter, 2004; Golikov et al., 2018; Nesis, 1965; Sennikov et al., 1989; Wiborg et al., 1984). Although Cd is strongly retained by cephalopods (Bustamante et al., 2002), there are two potential explanations for the $\mathrm{Cd}$ decrease with ontogeny. These include: 1) the diet of G. fabricii shifts from a Cd-rich diet (crustaceans) to a Cd-poor diet (fish); and/or 2) a fast growth rate in the juveniles results in a dilution of $\mathrm{Cd}$ in the growing tissues (Chouvelon et al. 2011). Predators that feed mainly on juvenile G. fabricii (e.g., Greenland halibut, Reinhardtius hippoglossoides, Dawe et al., 1998) could have an increased $\mathrm{Cd}$ intake relative to predators that preferentially feed on larger specimens (e.g., sperm whales Physeter macrocephalus, bottlenose whales Hyperoodon ampullatus, and narwhales Monodon monoceros, Bjørke, 2001; Laidre and Heide-Jørgensen, 2005).

Gonatus fabricii is an important prey item for top predators in the Arctic pelagic food web (Bjørke, 
2001; Bluhm and Gradinger, 2005), which could make it an important vector for Cd. The diet of the harbour porpoise, Phocoena phocoena, off Greenland contained squid, which have been suggested as the main source of Cd (Szefer et al., 2002). However, the Cd concentrations in the digestive gland of G. fabricii reported herein (4.36-63.14 $\mu \mathrm{g} . \mathrm{g}^{-1} \mathrm{dw}$; Table 1) are higher compared to those from the liver of P. phocoena from coastal Greenland (3.45 $\mu \mathrm{g} . \mathrm{g}^{-1} \mathrm{dw}$; Szefer et al., 2002). Similarly, Cd concentrations in the Greenland shark, Somniosus microcephalus (which primarily feeds on mammals and fish), were lower on average (i.e., $10.7 \pm 4.87 \mu \mathrm{g} . \mathrm{g}^{-1}$; Corsolini et al., 2014) than those measured in G. fabricii (Table 1). The energetic requirements of ectothermic fish and endothermic mammals differ and could impact Cd exposure and bioaccumulation (Jezierska and Witeska, 2006). In addition, the biological effects of cold Arctic waters can be significant and must be taken into account when comparing Cd accumulation in mammals and fishes (Sokolova and Lannig, 2008). There is a higher energetic cost associated with living in the Arctic compared to temperate oceans, and ingesting a large amount of squid could significantly contribute to the Cd exposure in predators (Bustamante et al., 1998a,b). Due to its importance in the diets of many predators (Bjørke, 2001) and high Cd concentrations (Table 1), G. fabricii from West-Greenland waters appear to be an important vector in the transfer of $\mathrm{Cd}$ in the Arctic pelagic food web.

\subsubsection{Mercury}

Mercury is a highly bioaccumulative metal and is known to cause neurological damage in various organisms including humans (Campbell et al., 2005). There is very little information on $\mathrm{Hg}$ concentrations in marine Arctic invertebrates (Fort et al., 2016) despite their key role in the arctic food web. Our results for $\mathrm{Hg}$ concentrations in the digestive gland ( 0.01 to $\left.0.11 \mu \mathrm{g} . \mathrm{g}^{-1} \mathrm{dw}\right)$ and mantle tissue (0.03 to $0.26 \mu \mathrm{g} . \mathrm{g}^{-1}$ ) were comparable to those reported for Berryteuthis magister, a gonatid from the Bering Sea $\left(\sim 0.21 \pm 0.11 \mu \mathrm{g} \cdot \mathrm{g}^{-1} \mathrm{dw}\right.$, converted from ww) (Cyr et al., 2019). In both tissues, Hg concentrations showed a positive linear correlation with size and trophic level (Table 1, 2). A correlation between size/age and $\mathrm{Hg}$ concentration has been previously shown in fish (Monteiro et al., 1996; Scott, 1974) and several cephalopod species (Chouvelon et; al. 2011; Lischka et al., 2018; Monteiro et al., 1992; Rossi et al., 1993; Storelli and Marcotrigiano, 1999). In addition, the link between trophic position and $\mathrm{Hg}$ concentrations in marine organisms is well documented (e.g., Phillips et al., 1980; Power et al., 2002), including cephalopods (Chouvelon et al., 2011). Furthermore, high concentrations $\left(\sim 0.33-2.44 \mu \mathrm{g} . \mathrm{g}^{-1} \mathrm{dw}\right)$ of $\mathrm{Hg}$ in marine mammals (e.g., ringed seal Phoca hispida, harp seal Phoca groenlandica, harbour porpoise Phocoena phocoena, minke whale Balaenoptera acutorostrata or narwhale Monodon monoceros) were previously reported from 
the Arctic (Dietz et al., 2000).

Detoxification mechanisms for $\mathrm{Hg}$ that involve Se have been reported for marine animals (Chen et al., 2006; Huang et al., 1995; Ralston et al., 2008; Storelli and Marcotrigiano, 1999). With increasing Hg concentrations, and trophic level, Se concentrations decrease (Fig. 4), this has been also shown for flying fish (Exocoetus volitans) and mitre squid (Uroteuthis chinensis) (Wang et al., 2018). The mantle tissue of G. fabricii showed a negative correlation between molar Se and Hg (Figs 4a, b). A bioreduction of Se concentrations with increasing trophic level has been well documented in the marine food web, but is still not fully understood (Stewart et al., 2010). The ontogenetic differences in $\mathrm{Hg}$ and Se concentrations observed herein could be explained by the dietary shift that occurs with maturation, with adult specimens feeding on $\mathrm{Hg}$ rich fishes and increasing their own $\mathrm{Hg}$ concentrations. It is assumed that a molar excess of $\mathrm{Hg}$ relative to Se indicates the storage of organic $\mathrm{Hg}$ in the tissues of marine taxa (Ralston et al., 2008). However, Se concentrations measured in our study for G. fabricii were several magnitudes higher than $\mathrm{Hg}$ concentrations, which is in concordance with data from other invertebrates from Greenland waters (Riget et al., 2007; Ritterhoff and Zauke, 1997). This could indicate an opposite trend where increased $\mathrm{Hg}$ concentration lead to decreased Se concentrations, or that $\mathrm{Hg}$ is stored by binding to muscular proteins without Se being involved in its metabolism.

\subsubsection{Lead}

Lead concentrations of G. fabricii found in the present study were higher in the digestive gland (0.03$\left.0.37 \mu \mathrm{g} . \mathrm{g}^{-1} \mathrm{dw}\right)$ than in the muscular tissue $\left(0.01-0.16 \mu \mathrm{g} \mathrm{g}^{-1} \mathrm{dw}\right)$, which showed a similar trend with concentrations previously reported for Todarodes filippovae (Kojadinovic et al., 2011). Lead appears to be mainly stored and detoxified in the digestive gland (Penicaud et al., 2017; Smith et al., 1984). Specimen size was significantly correlated with $\mathrm{Pb}$ concentrations in both digestive gland and muscle tissue, with higher concentrations found in juvenile specimens (Tables 1,2). This ontogenetic decrease in $\mathrm{Pb}$ concentrations can be explained by the dietary shift that occurs with maturation and $\mathrm{Pb}$ dilution with growth, because the accumulation of $\mathrm{Pb}$ in cephalopods is associated with feeding habits (Villanueva and Bustamante, 2006) and the bioreduction of $\mathrm{Pb}$ within food webs (Wang, 2002).

\subsubsection{Silver}

Silver concentrations showed a positive linear relationship with size, maturation stage, and stable isotope values. These relationships suggest an accumulation of Ag with age and trophic position. 
High concentrations of $\mathrm{Ag}$ in cephalopods have been previously reported in e.g. Ommastrephes bartrami and Sthenoteuthis oualaniensis (Martin and Flegal, 1975) and are likely the result of the high bioaccumulation capacities of cephalopods for this metal (Bustamante et al., 2004). In concordance with our measured concentrations, elevated Ag concentrations have often been observed together with high $\mathrm{Cu}$ concentrations, which are required for hemocyanin synthesis (Beuerlein et al., 2002; Martin and Flegal, 1975). The concentrations measured in this study are comparable to concentrations measured in Architeuthis dux (Bustamante et al., 2008; Table 4). Silver naturally occurs in the Earth's crust and shows a high affinity to sulphur ligands in seawater (Bell and Kramer, 1999; Dehn et al., 2006). Cephalopods are known to take up Ag from seawater (Bustamante et al., 2004; Miramand et al., 2006). Because of the vertical migration, adult G. fabricii could be exposed to higher Ag concentrations in deeper waters (Boyé et al., 2012; Zhang et al., 2004), creating an indirect link between Ag concentrations and trophic level. Our results suggest that G. fabricii could be a vector for the bioaccumulation of $\mathrm{Ag}$ in the food web. However, more research is needed on the concentrations of $\mathrm{Ag}$ in other Arctic predators to better understand the bioaccumulation of this trace element in the pelagic food web.

\subsection{Trace element correlations}

The highest $\mathrm{Cu}$ concentrations were found in the digestive gland of G. fabricii, which is considered the main storage organ for this metal (Finger and Smith, 1987; Miramand and Bentley, 1992). We found a correlation between $\mathrm{Cd}, \mathrm{Cu}$ and $\mathrm{Zn}$ in the digestive gland; however, the significance of this correlation varied between ontogenetic stages, with the highest correlation found between $\mathrm{Cd}$ and $\mathrm{Zn}$ in the digestive gland of juveniles. Copper and Zn are cofactors in digestive enzyme systems and are involved in hemocyanin synthesis (Bustamante et al., 2002; Smith et al., 1984). The role of $\mathrm{Cu}$ and $\mathrm{Zn}$ in the detoxification process of $\mathrm{Cd}$ in cephalopods has been previously discussed (e.g., Bustamante et al., 2002; Miramand and Bentley, 1992), and excessive metals in the digestive gland cells can be bound to metalloproteins (Jebali et al., 2008; Viarengo and Nott, 1993). In addition, the strong correlation found between $\mathrm{Zn}$ and $\mathrm{Cd}$ in juveniles likely indicates a stronger detoxification effect in the digestive gland, which is necessary due to the high $\mathrm{Cd}$ concentrations in their diet, rather than an inefficient $\mathrm{Cd}$ detoxification method that improves with maturity.

A correlation was observed between trace element concentrations of $\mathrm{Cr}$ and $\mathrm{Ni}$ in the digestive gland. The association of these two trace elements could be linked with anthropogenic activities. Elevated $\mathrm{Ni}$ concentrations in marine biota have been linked with mining activities and natural erosion (Bustamante et al., 2000; Pernice et al., 2009). The correlation of these two trace elements could be 
associated with their main commercial use, because steel production uses $\mathrm{Ni}$ as an alloy with $\mathrm{Cr}$ and both metals are associated in ores (Cano et al., 2014; Sedriks, 1982). Therefore, an accumulation of $\mathrm{Ni}$ could likely result in a correlated accumulation of its associated metals (e.g., Co, Cr, Mn; Metian et al., 2008; Monniot et al., 1994). Both $\mathrm{Ni}$ and $\mathrm{Cr}$ can impact pelagic food webs through the bioconcentration in invertebrates and their predators (Campbell et al., 2005).

\subsection{Gonatus fabricii as a vector of trace elements}

Our results indicate that Gonatus fabricii is an important vector for the transfer of contaminants into the deep-sea pelagic food web due to its high abundance, its role as dominant prey and its ontogenetic migration into deeper waters. In addition, G. fabricii may also transfer contaminants to benthic and benthopelagic food webs via benthic-pelagic coupling. Gonatids undergo a single reproductive cycle (semelparous life strategy) (Boyle and Rodhouse, 2005; Laptikhovsky et al., 2007). Females hold on to the eggs in the water column during an extensive brooding period (likely $\sim 2$ years) as has been observed for G. onyx in Monterey Canyon, off California at depths between 1,539 and 2,522 m (Seibel et al 2005), which is followed by death. After death, Pacific gonatids sink to the seafloor where they represent an important food source for scavenging fauna (Hoving et al., 2017). Similarly, postspawning carcasses of $G$. fabricii in the northern Atlantic are likely consumed by benthic scavenging fauna including fish (e.g., grenadiers, Coryphaenoides spp.; Martin and Christiansen, 1997) but in situ observations of gonatid carcasses remain undocumented from the Atlantic. Trace elements are accumulated with increasing trophic level in the deep pelagic ocean (Atwell et al., 1998; Campbell et al., 2005). The combination of ontogenetic migration, high abundance, terminal spawning, and the accumulation of trace elements along the pelagic food chain via consumption of meso-and bathypelagic fishes by $\mathrm{G}$. fabricii suggests that significant amounts of $\mathrm{Cd}$ and $\mathrm{Hg}$ may be transported to the deep-sea. Sinking carcasses of spent G. fabricii may then potentially introduce these contaminants to the benthic food web via scavengers. Future studies should focus on $\mathrm{Cd}$ and $\mathrm{Hg}$ concentrations in benthic scavengers of the northern seas to test this hypothesis.

\section{Conclusion}

Overall, trace element concentrations measured in G. fabricii, collected in 2005 off West Greenland, were relatively low when compared to loliginid or ommastrephid squids. However, we found significant differences in trace element accumulation, in particular for $\mathrm{Cd}$, with maturity stage and trophic position. Our findings suggest that concentrations of most trace elements vary with size in $G$. fabricii and support an ontogenetic change in diet. This implies that in the pelagic Arctic food web, 
the transfer of trace elements to predators depends on the size/age class of the squids. Predators that feed mainly on juvenile G. fabricii (e.g. Greenland halibut) might have an increased Cd intake compared to predators mainly feeding on adult specimens, (e.g., sperm whales, bottlenose whales and narwhales). Conversely, $\mathrm{Hg}$ levels were higher in mature individuals and would have a stronger effect on predators that feed predominantly on mature G. fabricii. Future studies should be conducted on $G$. fabricii and other cephalopod species in Arctic waters in order to clarify our understanding of the element transfers in the marine Arctic food web, which will be crucial for tracing the bioaccumulation of contaminants in Arctic marine mammals, birds, and predatory fishes.

\section{Acknowledgments}

We thank Rikke Petri Frandsen and the crew of the R/V Paamiut for the specimens, and Helle Siegstad for providing valuable information on the specimen data. The authors are grateful to C. Churlaud and M. Brault-Favrou from the Plateforme "Analyses Elémentaires" of LIENSs for their support during the trace element analysis and to G. Guillou from the Plateforme "Analyses Isotopiques" of LIENSs for running the stable isotope analysis. Thanks to the CPER (Contrat de Projet Etat-Région) and the FEDER (Fonds Européen de Développement Régional) for funding the ICPs, the AMA, and the IRMS of LIENSs laboratory. The IUF (Institut Universitaire de France) is acknowledged for its support to PB as a Senior Member. We also thank the German Research Foundation (DFG) for financial support under grant HO 5569/1-2 (Emmy Noether Junior Research Group) awarded to HJTH. Thanks to Unitas Malacologica for funding the research travels of AL.

\section{References}

AMAP, 2018. AMAP Assessment 2018: Biological Effects of Contaminants on Arctic Wildlife and Fish Key Messages.

Arkhipkin, A.I., Bjørke, H., 1999. Ontogenetic changes in morphometric and reproductive indices of the squid Gonatus fabricii (Oegopsida, Gonatidae) in the Norwegian Sea. Polar Biology 22, 357-365.

Atwell, L., Hobson, K.A., Welch, H.E., 1998. Biomagnification and bioaccumulation of mercury in an arctic marine food web: insights from stable nitrogen isotope analysis. Canadian Journal of Fisheries and Aquatic Sciences 55, 1114-1121.

Bargagli, R., Sanchez-Hernandez, J.C., Monaci, F., Focardi, S., 2000. Environmental factors promoting bioaccumulation of $\mathrm{Hg}$ and $\mathrm{Cd}$ in Antarctic marine and terrestrial organisms. Antarctic ecosystems: models for wider ecological understanding (ed. W. Davison, C. Howard-Williams \& P. Broady) 308-314.

Barrie, L.A., Gregor, D., Hargrave, B., Lake, R., Muir, D., Shearer, R., Tracey, B., Bidleman, T., 1992. Arctic contaminants: sources, occurrence and pathways. Science of the Total 
Environment 122, 1-74.

Becker, P.R., 2000. Concentration of chlorinated hydrocarbons and heavy metals in Alaska Arctic marine mammals. Marine Pollution Bulletin 40, 819-829.

Bell, R.A., Kramer, J.R., 1999. Structural chemistry and geochemistry of silver-sulfur compounds: critical review. Environmental Toxicology and Chemistry 18, 9-22.

Beuerlein, K., Ruth, P., Westermann, B., Löhr, S., Schipp, R., 2002. Hemocyanin and the branchial heart complex of Sepia officinalis: are the hemocytes involved in hemocyanin metabolism of coleoid cephalopods? Cell \& Tissue Research 310, 373-381.

Bjørke, H., Hansen, K., Sundt, R.C., 1997. Egg masses of the squid Gonatus fabricii (Cephalopoda, Gonatidae) caught with pelagic trawl off northern Norway. Sarsia 82, 149-152.

Bjørke, H., 2001. Predators of the squid Gonatus fabricii (Lichtenstein) in the Norwegian Sea. Fisheries Research 52, 113-120.

Bjørke, H., Gjøsæter, H., 2004. Cephalopods in the Norwegian Sea. In Skjoldal. H.R. (Ed.): The Norwegian Sea Ecosystem. Tapir Academic Press, Trondheim, pp. 371-394.

Bluhm, B.A. and Gradinger, R., 2008. Regional variability in food availability for Arctic marine mammals. Ecological Applications, 18(sp2), S77-S96.

Boutron, C.F., Candelone, J.-P., Hong, S., 1994. Past and recent changes in the large-scale tropospheric cycles of lead and other heavy metals as documented in Antarctic and Greenland snow and ice: a review. Geochimica et Cosmochimica Acta 58, 3217-3225.

Boyé, M., Wake, B., Garcia, P.L., Bown, J., Baker, A.R., Achterberg, E.P., 2012. Distributions of dissolved trace metals $(\mathrm{Cd}, \mathrm{Cu}, \mathrm{Mn}, \mathrm{Pb}, \mathrm{Ag})$ in the southeastern Atlantic and the Southern Ocean. Biogeosciences 9, 3231-3246.

Boyle, P., Rodhouse, P., 2005. Cephalopods as prey. Cephalopods-Ecology and Fisheries. Blackwell Publishing, Oxford 234-258.

Bustamante, P., Caurant, F., Fowler, S.W., Miramand, P., 1998a. Cephalopods as a vector for the transfer of cadmium to top marine predators in the north-east Atlantic Ocean. Science of the Total Environment 220, 71-80.

Bustamante, P., Cherel, Y., Caurant, F., Miramand, P., 1998b. Cadmium, copper and zinc in octopuses from Kerguelen Islands, Southern Indian Ocean. Polar Biology 19, 264-271.

Bustamante, P., Cosson, R.P., Gallien, I., Caurant, F., Miramand, P., 2002. Cadmium detoxification processes in the digestive gland of cephalopods in relation to accumulated cadmium concentrations. Marine Environmental Research 53, 227-241.

Bustamante, P., Grigioni, S., Boucher-Rodoni, R., Caurant, F., Miramand, P., 2000. Bioaccumulation of 12 trace elements in the tissues of the nautilus Nautilus macromphalus from New Caledonia. Marine Pollution Bulletin 40, 688-696.

Bustamante, P., Bocher, P., Cherel, Y., Miramand, P., Caurant, F., 2003. Distribution of trace elements in the tissues of benthic and pelagic fish from the Kerguelen Islands. Science of the Total Environment 313, 25-39.

Bustamante, P., Teyssié, J.-L., Danis, B., Fowler, S., Miramand, P., Cotret, O., Warnau, M., 2004. Uptake, transfer and distribution of silver and cobalt in tissues of the common cuttlefish Sepia officinalis at different stages of its life cycle. Marine Ecology Progress Series 269, 185-195.

Bustamante, P., Lahaye, V., Durnez, C., Churlaud, C., Caurant, F., 2006. Total and organic Hg concentrations in cephalopods from the North Eastern Atlantic waters: influence of geographical origin and feeding ecology. Science of the Total Environment 368, 585-596.

Bustamante P, González AF, Rocha F, Miramand P, Guerra A (2008) Metal and metalloid concentrations in the giant squid Architeuthis dux from Iberian waters. Marine Environmental Research, 66(2): 278-287.

Campbell, L.M., Norstrom, R.J., Hobson, K.A., Muir, D.C., Backus, S., Fisk, A.T., 2005. Mercury and other trace elements in a pelagic Arctic marine food web (Northwater Polynya, Baffin 
Bay). Science of the Total Environment 351, 247-263.

Cano, H., Neff, D., Morcillo, M., Dillmann, P., Diaz, I., de la Fuente, D., 2014. Characterization of corrosion products formed on $\mathrm{Ni} 2.4 \mathrm{wt} \%-\mathrm{Cu} 0.5 \mathrm{wt} \%-\mathrm{Cr} 0.5 \mathrm{wt} \%$ weathering steel exposed in marine atmospheres. Corrosion Science 87, 438-451.

Chen, C., Yu, H., Zhao, J., Li, B., Qu, L., Liu, S., Zhang, P., Chai, Z., 2006. The roles of serum selenium and selenoproteins on mercury toxicity in environmental and occupational exposure. Environmental Health Perspectives 114, 297-301.

Cherel, Y., Hobson, K.A., 2005. Stable isotopes, beaks and predators: a new tool to study the trophic ecology of cephalopods, including giant and colossal squids. Proceedings of the Royal Society of London B Biological Sciences 272, 1601-1607.

Chouvelon, T., Chappuis, A., Bustamante, P., Lefebvre, S., Mornet, F., Guillou, G., Violamer, L., Dupuy, C., 2014. Trophic ecology of European sardine Sardina pilchardus and European anchovy Engraulis encrasicolus in the Bay of Biscay (north-east Atlantic) inferred from $\delta 13 \mathrm{C}$ and $\delta 15 \mathrm{~N}$ values of fish and identified mesozooplanktonic organisms. Journal of Sea Research 85, 277-291.

Chouvelon, T., Spitz, J., Cherel, Y., Caurant, F., Sirmel, R., Mèndez-Fernandez, P., Bustamante, P., 2011. Inter-specific and ontogenic differences in $\delta 13 \mathrm{C}$ and $\delta 15 \mathrm{~N}$ values and $\mathrm{Hg}$ and $\mathrm{Cd}$ concentrations in cephalopods. Marine Ecology Progress Series 433, 107-120. https://doi.org/10.3354/meps09159

Corsolini, S., Ancora, S., Bianchi, N., Mariotti, G., Leonzio, C., Christiansen, J.S., 2014. Organotropism of persistent organic pollutants and heavy metals in the Greenland shark Somniosus microcephalus in NE Greenland. Marine Pollution Bulletin 87, 381-387.

Craig, S., Overnell, J., 2003. Metals in squid, Loligo forbesi, adults, eggs, and hatchlings. No evidence for a role for $\mathrm{Cu}$ - or $\mathrm{Zn}$-metallothionein. Comparative Biochemistry and Physiology 34C, 311-317.

Cuvin-Aralar, M.L.A., Furness, R.W., 1991. Mercury and selenium interaction: a review. Ecotoxicology and Environmental Safety 21, 348-364.

Cyr, A., López, J. A., Rea, L., Wooller, M. J., Loomis, T., Mcdermott, S., \& O'Hara, T. M. (2019). Mercury concentrations in marine species from the Aleutian Islands: Spatial and biological determinants. Science of The Total Environment 664, 761-770.

Dawe E.G., Bowering W.R., Joy J.B., 1998. Predominance of squid (Gonatus spp.) in the diet of Greenland halibut (Reinhardtius hippoglossoides) on the deep slope of the northeast Newfoundland continental shelf. Fisheries Research 36(2-3), 267-73.

Dehn, L.-A., Follmann, E.H., Thomas, D.L., Sheffield, G.G., Rosa, C., Duffy, L.K., O’Hara, T.M., 2006. Trophic relationships in an Arctic food web and implications for trace metal transfer. Science of the Total Environment 362, 103-123.

DeNiro, M.J., Epstein, S., 1978. Influence of diet on the distribution of carbon isotopes in animals. Geochimica et cosmochimica acta 42, 495-506.

DeNiro, M.J., Epstein, S., 1981. Influence of diet on the distribution of nitrogen isotopes in animals. Geochimica et Cosmochimica Acta 45, 341-351.

Dietz, R., Riget, F., Johansen, P., 1996. Lead, cadmium, mercury and selenium in Greenland marine animals. Science of the Total Environment 186, 67-93.

Dietz, R., Riget, F., Born, E.W., 2000. An assessment of selenium to mercury in Greenland marine animals. Science of the Total Environment 245, 15-24.

Dorneles, P.R., Lailson-Brito, J., dos Santos, R.A., Silva da Costa, P.A., Malm, O., Azevedo, A.F., Machado Torres, J.P., 2007. Cephalopods and cetaceans as indicators of offshore bioavailability of cadmium off Central South Brazil Bight. Environmental Pollution 148, 352-359.

Falandysz, J., 1988. Trace metals in squid Illex argentinus. Zeitschrift für LebensmittelUntersuchung und Forschung 187, 359-361. 
Finger, J.M., Smith, J.D., 1987. Molecular association of $\mathrm{Cu}, \mathrm{Zn}, \mathrm{Cd}$ and 210Po in the digestive gland of the squid Nototodarus gouldi. Marine Biology 95, 87-91.

Fort, J., Grémillet, D., Traisnel, G., Amélineau, F., Bustamante, P., 2016. Does temporal variation of mercury levels in Arctic seabirds reflect changes in global environmental contamination, or a modification of Arctic marine food web functioning? Environmental Pollution 211, 382-388.

Francesconi, K.A., Moore, E.J., Joll, L.M., 1993. Cadmium in the saucer scallop, Amusium balloti, from western Australian waters: concentrations in adductor muscle and redistribution following frozen storage. Marine and Freshwater Research 44, 787-797.

Frandsen, R.P., Wieland, K., 2004. Cephalopods in Greenland waters. Pinngortitaleriffik, Greenland Institute of Natural Resources.

Galván-Magaña, F., Márquez-Farías, J.F., Niño-Torres, C.A., 2012. Feeding ecology and trophic level of the banded guitarfish, Zapteryx exasperata, inferred from stable isotopes and stomach contents analysis. Environmental Biology of Fishes 95, 65-77.

Gao, X., Chen, C.-T.A., 2012. Heavy metal pollution status in surface sediments of the coastal Bohai Bay. Water Research 46, 1901-1911.

García, E.M., Cruz-Motta, J.J., Farina, O., Bastidas, C., 2008. Anthropogenic influences on heavy metals across marine habitats in the western coast of Venezuela. Continental Shelf Research 28, 2757-2766.

Gardiner, K., Dick, T.A., 2010. Arctic cephalopod distributions and their associated predators. Polar Research 29, 209-227.

Gerpe, M.S., de Moreno, J.E.A., Moreno, V.J., Patat, M.L., 2000. Cadmium, zinc and copper accumulation in the squid Illex argentinus from the Southwest Atlantic Ocean. Marine Biology 136, 1039-1044.

Gilly, W.F., 2005. Spreading and stranding of Humboldt squid. Ecosystem Observations for the Monterey Bay National Marine Sanctuary, 20-22.

Golikov, A.V., Sabirov, R.M., Lubin, P.A., Jørgensen, L.L., 2013. Changes in distribution and range structure of Arctic cephalopods due to climatic changes of the last decades. Biodiversity 14, 28-35.

Golikov, A.V., Ceia, F.R., Sabirov, R.M., Zaripova, Z.I., Blicher, M.E., Zakharov, D.V., Xavier, J.C., 2018. Ontogenetic changes in stable isotope $(\delta 13 \mathrm{C}$ and $\delta 15 \mathrm{~N})$ values in squid Gonatus fabricii (Cephalopoda) reveal its important ecological role in the Arctic. Marine Ecology Progress Series 606, 65-78.

Graf, U., 2004. z-Transformation, in: Applied Laplace Transforms and Z-Transforms for Scientists and Engineers. Springer, pp. 77-113.

Graham, B.S., Koch, P.L., Newsome, S.D., McMahon, K.W., Aurioles, D., 2010. Using isoscapes to trace the movements and foraging behavior of top predators in oceanic ecosystems, in: Isoscapes. Springer, pp. 299-318.

Hobson, K.A., 1999. Tracing origins and migration of wildlife using stable isotopes: a review. Oecologia 120, 314-326.

Hoving, H.-J.T., Robison, B.H., 2016. Deep-sea in situ observations of gonatid squid and their prey reveal high occurrence of cannibalism. Deep Sea Research Part I 116, 94-98.

Hoving, H.-J.T., Bush, S.L., Haddock, S.H.D., Robison, B.H., 2017. Bathyal feasting: postspawning squid as a source of carbon for deep-sea benthic communities. Proceedings of the Royal Society B: Biological Sciences 284, 20172096.

Huang, W., Åkesson, B., Svensson, B.G., Schütz, A., Burk, R.F., Skerfving, S., 1995. Selenoprotein $\mathrm{P}$ and glutathione peroxidase (EC 111 1.9) in plasma as indices of selenium status in relation to the intake of fish. British Journal of Nutrition 73, 455-461.

Ichihashi, H., Kohno, H., Kannan, K., Tsumura, A., Yamasaki, S., 2001. Multielemental Analysis of Purpleback Flying Squid Using High Resolution Inductively Coupled Plasma-Mass 
Spectrometry (HR ICP-MS). Environmental Science \& Technology 35, 3103-3108.

Ihaka, R. and Gentleman, R., 1996. R: A language for data analysis and graphics. Journal of Computational and Graphical Statistics 5, 299-314.

Ijsseldijk, L.L., van Neer, A., Deaville, R., Begeman, L., van de Bildt, M., van den Brand, J.M.A., Brownlow, A., Czeck, R., Dabin, W., ten Doeschate, M., Herder, V., Herr, H., IJzer, J., Jauniaux, T., Jensen, L.F., Jepson, P.D., Jo, W.K., Lakemeyer, J., Lehnert, K., Leopold, M.F., Osterhaus, A., Perkins, M., Piatkowski, U., Prenger-Berninghoff, E., Pund, R., Wohlsein, P., Gröne, A., Siebert, U., 2018. Beached bachelors: An extensive study on the largest recorded sperm whale Physeter macrocephalus mortality event in the North Sea. PLoS ONE 13(8): e0201221. https://doi.org/10.1371/journal.pone.0201221

Ishizaki, A., Fukushima, M., Sakamoto, M., 1970. Distribution of Cd in Biological Materials Part 2. Nippon Eiseigaku Zasshi (Japanese Journal of Hygiene) 25, 207-222.

Jebali, J., Banni, M., Gerbej, H., Boussetta, H., López-Barea, J., Alhama, J., 2008. Metallothionein induction by $\mathrm{Cu}, \mathrm{Cd}$ and $\mathrm{Hg}$ in Dicentrarchus labrax liver: assessment by RP-HPLC with fluorescence detection and spectrophotometry. Marine Environmental Research 65, 358363.

Jezierska, B. and Witeska, M., 2006. The metal uptake and accumulation in fish living in polluted waters. Soil and water pollution monitoring, protection and remediation, 107-114

Kojadinovic, J., Jackson, C.H., Cherel, Y., Jackson, G.D., Bustamante, P., 2011. Multi-elemental concentrations in the tissues of the oceanic squid Todarodes filippovae from Tasmania and the southern Indian Ocean. Ecotoxicology and Environmental Safety 74, 1238-1249. https://doi.org/10.1016/j.ecoenv.2011.03.015

Kristensen, T.K., 1983. Gonatus fabricii, in: Boyle, P.R. (Ed.), Cephalopod Life Cycles, Volume 1, Species Accounts. Academic Press, London, 159-173.

Kristensen, T.K., 1984. Biology of the squid Gonatus fabricii (Lichtenstein, 1818) from West Greenland waters. Meddelelser om Grønland, Bioscience 13, 1-20. .

Kurihara, H., Togawa, H., Hatano, M., 1993. Concentration of cadmium in livers of several kinds of squids and an approach to its elimination. Bulletin of the Faculty of Fisheries, Hokkaido University 44, 32-38.

Laidre, K.L., Heide-Jørgensen, M.P., 2005. Winter feeding intensity of narwhals (Monodon monoceros). Marine Mammal Science 21, 45-57.

Langston, W.J., 1990. Toxic effects of metals and the incidence of metal pollution in marine ecosystems, in: Furness, R.W., Rainbow, P.S. (Eds.), Heavy Metals in the Marine Environment. Boca Raton, CRC Press, 101-122.

Laptikhovsky, V.V., Arkhipkin, A.I., Hoving, H.J.T., 2007. Reproductive biology in two species of deep-sea squids. Marine Biology 152, 981-990.

Lichtenstein, H.C., 1818. Onychoteuthis, Sepien mit Krallen. Isis oder Encyclopadische Zeitung 9, 1591-1592.

Lischka, A., Lacoue-Labarthe, T., Hoving, H.J.T., JavidPour, J., Pannell, J.L., Merten, V., Churlaud, C., Bustamante, P., 2018. High cadmium and mercury concentrations in the tissues of the orange-back flying squid, Sthenoteuthis pteropus, from the tropical Eastern Atlantic. Ecotoxicology and Environmental Safety 163, 323-330. https://doi.org/10.1016/j.ecoenv.2018.07.087

Lischka, A., Pook, C.J., Bolstad, K.S.R., Pannell, J.L., Braid, H.E., 2019. Metal composition of arrow squid (Nototodarus sloanii [Gray 1849]) from the Chatham Rise, New Zealand: implications for human consumption. Environmental Science and Pollution Research 26, 11975-11987 https://doi.org/10.1007/s11356-019-04510-w

Lischka, A., Pook, C.J., Pannell, J.L., Braid, H.E., Gaw, S., Bolstad, K.S.R. Distribution of trace elements in the tissues of arrow squid (Nototodarus sloanii) from the Chatham Rise, New Zealand: Human health implications. Fisheries Research [in press]. 
Lucia, M., Strøm, H., Bustamante, P., Gabrielsen, G.W., 2016. Trace element concentrations in relation to the trophic behaviour of endangered Ivory Gulls (Pagophila eburnea) during their stay at a breeding site in Svalbard. Archives of Environmental Contamination and Toxicology $71,518-529$.

Lund, L., 2018. Labor Market and Current Account Equilibria in Greenland. Nationaløkonomisk Tidsskrift 156.

Macdonald, C.R., Sprague, J.B., 1988. Cadmium in marine invertebrates and arctic cod in the Canadian Arctic. Distribution and ecological implications. Marine Ecology Progress Series 47, 17-30.

Martin, J.H., Flegal, A.R., 1975. High copper concentrations in squid livers in association with elevated levels of silver, cadmium, and zinc. Marine Biology 30, 51-55.

Martin, A.R., Clarke, M.R., 1986. The diet of sperm whales (Physeter macrocephalus) captured between Iceland and Greenland. Journal of the Marine Biological Association of the United Kingdom 66, 779-790.

Martin, B., Christiansen, B., 1997. Diets and standing stocks of benthopelagic fishes at two bathymetrically different midoceanic localities in the northeast Atlantic. Deep Sea Research Part I 44, 541-558.

McConnell, J.R., Edwards, R., 2008. Coal burning leaves toxic heavy metal legacy in the Arctic. Proceedings of the National Academy of Sciences 105, 12140-12144.

Merten, V., Christiansen, B., Javidpour, J., Piatkowski, U., Puebla, O., Gasca, R., Hoving, H.-J.T., 2017. Diet and stable isotope analyses reveal the feeding ecology of the orangeback squid Sthenoteuthis pteropus (Steenstrup 1855) (Mollusca, Ommastrephidae) in the eastern tropical Atlantic. PloS ONE 12, e0189691.

Metian, M., Giron, E., Borne, V., Hédouin, L., Teyssié, J.-L., Warnau, M., 2008. The brown alga Lobophora variegata, a bioindicator species for surveying metal contamination in tropical marine environments. Journal of Experimental Marine Biology and Ecology 362, 49-54.

Miramand, P., Bentley, D., 1992. Concentration and distribution of heavy metals in tissues of two cephalopods, Eledone cirrhosa and Sepia officinalis, from the French coast of the English Channel. Marine Biology 114, 407-414.

Miramand, P., Bustamante, P., Bentley, D. and Kouéta, N., 2006. Variation of heavy metal concentrations (Ag, Cd, Co, $\mathrm{Cu}, \mathrm{Fe}, \mathrm{Pb}, \mathrm{V}$, and $\mathrm{Zn}$ ) during the life cycle of the common cuttlefish Sepia officinalis. Science of the Total Environment, 361(1-3): 132-143.

Monniot, F., Martoja, R., Monniot, C., 1994. Cellular sites of iron and nickel accumulation in ascidians related to the naturally and anthropic enriched New Caledonian environment, in: Annales de l'Institut Oceanographique, Paris. Nouvelle Serie. Paris. pp. 205-216.

Monteiro, L.R., Porteiro, F.M., Gonçalves, J.M., 1992. Inter- and intra-specific variation of mercury levels in muscle of cephalopods from the Azores. Arquipelago. Serie Ciencias da Natureza $13-22$.

Monteiro, L.R., Costa, V., Furness, R.W., Santos, R.S., 1996. Mercury concentrations in prey fish indicate enhanced bioaccumulation in mesopelagic environments. Marine Ecology Progress Series 141, 21-25.

Muir, D.C., Wagemann, R., Hargrave, B.T., Thomas, D.J., Peakall, D.B., Norstrom, R.J., 1992. Arctic marine ecosystem contamination. Science of the Total Environment 122, 75-134.

Nesis, K.N., 1965. Distribution and feeding of young squids Gonatus fabricii (Licht) in the Labrador Sea and the Norwegian Sea. Oceanology 5, 102-108.

Nesis, K.N., 1971. The squid Gonatus fabricii (Licht.) in the center of the Arctic Basin. Gidrobiologichesky Zhurnal 7, 93-96.

Nesis, K.N., 2001. West-Arctic and East-Arctic distributional ranges of cephalopods. Sarsia 86, 111.

Orr, D.C., Bowering, W.R., 1997. A multivariate analysis of food and feeding trends among 
Greenland halibut (Reinhardtius hippoglossoides) sampled in Davis Strait, during 1986. ICES Journal of Marine Science 54, 819-829.

Penicaud, V., Lacoue-Labarthe, T., Bustamante, P., 2017. Metal bioaccumulation and detoxification processes in cephalopods: A review. Environmental Research 155, 123-133. https://doi.org/10.1016/j.envres.2017.02.003

Pernice, M., Boucher, J., Boucher-Rodoni, R., Joannot, P., Bustamante, P., 2009. Comparative bioaccumulation of trace elements between Nautilus pompilius and Nautilus macromphalus (Cephalopoda: Nautiloidea) from Vanuatu and New Caledonia. Ecotoxicology and Environmental Safety 72, 365-371.

Petri, G., Zauke, G.-P., 1993. Trace metals in crustaceans in the Antarctic Ocean. Ambio-Journal of Human Environment Research and Management 22, 529-536.

Phillips, G.R., Lenhart, T.E., Gregory, R.W., 1980. Relation between trophic position and mercury accumulation among fishes from the Tongue River Reservoir, Montana. Environmental Research 22, 73-80.

Piatkowski, U.,Wieland, K., 1993. The Boreoatlantic gonate squid Gonatus fabricii: distribution and size off West Greenland in summer 1989 and in summer and autumn 1990. Aquatic Living Resources, 6(2), 109-114.

Power, M., Klein, G.M., Guiguer, K., Kwan, M.K.H., 2002. Mercury accumulation in the fish community of a sub-Arctic lake in relation to trophic position and carbon sources. Journal of Applied Ecology 39, 819-830.

Ralston, N.V., Ralston, C.R., Blackwell III, J.L., Raymond, L.J., 2008. Dietary and tissue selenium in relation to methylmercury toxicity. Neurotoxicology $29,802-811$.

Riget, F., Møller, P., Dietz, R., Nielsen, T.G., Asmund, G., Strand, J., Larsen, M.M. and Hobson, K.A., 2007. Transfer of mercury in the marine food web of West Greenland. Journal of Environmental Monitoring 9(8), 877-883.

Ritterhoff, J., Zauke, G.-P., 1997. Bioaccumulation of trace metals in Greenland Sea copepod and amphipod collectives on board ship: verification of toxicokinetic model parameters. Aquatic Toxicology 40, 63-78.

Rossi, A., Pellegrini, D., Belcari, P., Barghigiani, C., 1993. Mercury in Eledone cirrhosa from the northern Tyrrhenian sea: Contents and relations with life cycle. Marine Pollution Bulletin 26, 683-686.

Santos, M.B., Pierce, G.J., Boyle, P.R., Reid, R.J., Ross, H.M., Patterson, I.A.P., Kinze, C.C., Tougaard, S. Lick, R., Piatkowski, U., Hernández-García, V., 1999. Stomach contents of sperm whales Physeter macrocephalus stranded in the North Sea 1990-1996. Marine Ecology Progress Series 183, 281-294.

Savinov, V.M., Gabrielsen, G.W., Savinova, T.N., 2003. Cadmium, zinc, copper, arsenic, selenium and mercury in seabirds from the Barents Sea: levels, inter-specific and geographical differences. Science of the Total Environment 306, 133-158.

Scott, D.P., 1974. Mercury concentration of white muscle in relation to age, growth, and condition in four species of fishes from Clay Lake, Ontario. Journal of the Fisheries Board of Canada $31,1723-1729$.

Sedriks, A.J., 1982. Corrosion resistance of austenitic Fe-Cr-Ni-Mo alloys in marine environments. International Metals Reviews 27, 321-353.

Seibel, B.A., Robison, B.H., Hadock, S.H.D., 2005. Post-spawning egg care by a squid. Nature 438, 929.

Sennikov, A.M., Mukhin, S.G., Bliznichenko, T.E., 1989. Distribution and trophic importance of juvenile squid (Gonatus fabricii Lichtenstein) in the Norwegian and Barents Seas in 19861988. ICES Council Meeting, C.M. 1989/K:15, 18.

Smith, J.D., Plues, L., Heyraud, M., Cherry, R.D., 1984. Concentrations of the elements Ag, Al, Ca, $\mathrm{Cd}, \mathrm{Cu}, \mathrm{Fe}, \mathrm{Mg}, \mathrm{Mn}, \mathrm{Pb}$ and $\mathrm{Zn}$, and the radionuclides ${ }^{210} \mathrm{~Pb}$ and ${ }^{210} \mathrm{Po}$ in the digestive gland 
of the squid Nototodarus gouldi. Marine Environmental Research 13, 55-68.

Sokolova, I.M., Lannig, G., 2008. Interactive effects of metal pollution and temperature on metabolism in aquatic ectotherms: implications of global climate change. Climate Research 37, 181-201.

Stewart, R., Grosell, M., Buchwalter, D., Fisher, N., Luoma, S., Mathews, T., Orr, P., Wang, W.-X., 2010. Bioaccumulation and trophic transfer of selenium, in: Ecological Assessment of Selenium in the Aquatic Environment. CRC Press, pp. 109-155.

Storelli, M.M., Marcotrigiano, G.O., 1999. Cadmium and total mercury in some cephalopods from the South Adriatic Sea (Italy). Food Additives and Contaminants 16, 261-265.

Szefer, P., Zdrojewska, I., Jensen, J., Lockyer, C., Skora, K., Kuklik, I., Malinga, M., 2002. Intercomparison studies on distribution and coassociations of heavy metals in liver, kidney, and muscle of harbor porpoise, Phocoena phocoena, from southern Baltic Sea and coastal waters of Denmark and Greenland. Archives of Environmental Contamination and Toxicology 42, 508-522.

Takeuchi, S., Kimoto, I., Mamo, M., Tomioka, E., Sasaki, T., Nakamura, H., Mathunaga, Y., Fukamizu, S., Ochiai, A., Kimizuka, K., 1979. Physiological significance of heavy metal (Cd) in squid liver. Biomedical Research on Trace Elements 1, 279-280.

Tchounwou, P.B., Yedjou, C.G., Patlolla, A.K., Sutton, D.J., 2012. Heavy metal toxicity and the environment, in: Molecular, Clinical and Environmental Toxicology. Springer, pp. 133-164.

Viarengo, A., Nott, J.A., 1993. Mechanisms of heavy metal cation homeostasis in marine invertebrates. Comparative Biochemistry and Physiology Part C: Comparative Pharmacology 104, 355-372.

Villanueva, R., Bustamante, P., 2006. Composition in essential and non-essential elements of early stages of cephalopods and dietary effects on the elemental profiles of Octopus vulgaris paralarvae. Aquaculture 261, 225-240.

Vu, V.Q., 2011. ggbiplot: A ggplot2 based biplot. R package.

Wang, W. X. (2002). Interactions of trace metals and different marine food chains. Marine Ecology Progress Series 243, 295-309.

Wang, X., Wu, L., Sun, J., Wei, Y., Zhou, Y., Rao, Z., Yuan, L., Liu, X., 2018. Mercury Concentrations and Se: Hg Molar Ratios in Flyingfish (Exocoetus volitans) and Squid (Uroteuthis chinensis). Bulletin of Environmental Contamination andToxicology 101, 42 48.

Wiborg, K.F., Gjøsæter, H., Beck, I.M., 1984. The squid Gonatus fabricii (Lichtenstein). Investigations in the Norwegian Sea and the western Barents Sea, 1982-1983. ICES Council Meeting C.M. 1984/K:19, 14pp.

Wright, K., 2012. Corrgram: Plot a correlogram. R package version 1.

Young, R.E., 1973. Evidence for spawning by Gonatus sp. (Cephalopoda: Teuthoidea) in the high Arctic Ocean. The Nautilus 87 (2), 53-58.

Zauke, G.-P., Savinov, V.M., Ritterhoff, J., Savinova, T., 1999. Heavy metals in fish from the Barents Sea (summer 1994). Science of the Total Environment 227, 161-173.

Zhang, Y., Obata, H., Nozaki, Y., 2004. Silver in the Pacific Ocean and the Bering Sea. Geochemical Journal 38, 623-633.

Zumholz, K., Frandsen, R.P., 2006. New information on the life history of cephalopods off west Greenland. Polar Biology 29, 169-178.

Zumholz, K.,Klügel, A., Hansteen, T., Piatkowski, U., 2007. Statolith microchemistry traces the environmental history of the boreoatlantic armhook squid Gonatus fabricii. Marine Ecology Progress Series 333, 195-204. 


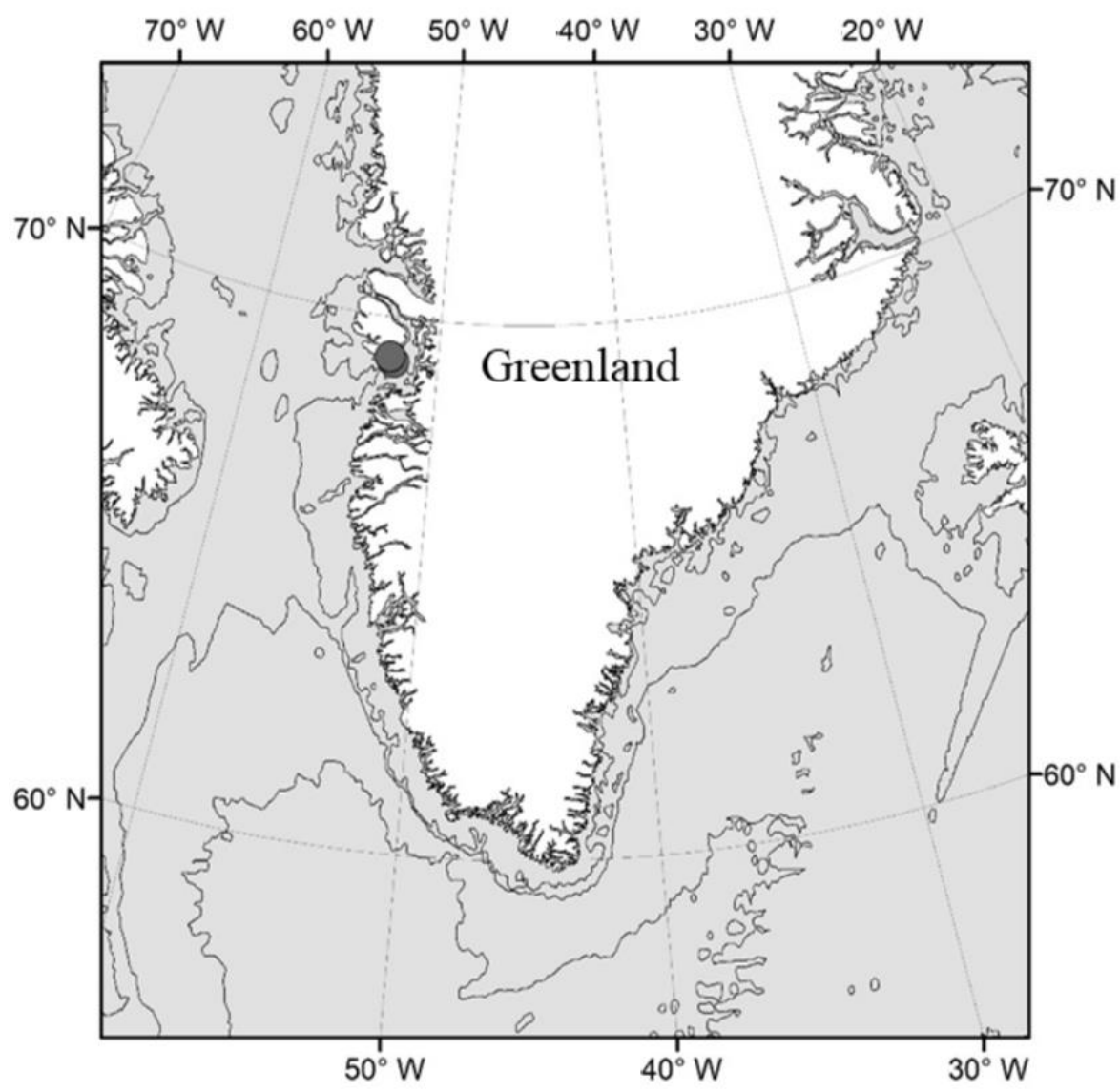

Figure 1. Map of the sampling area during the cruise, the sampling station is are indicated by grey circles. 


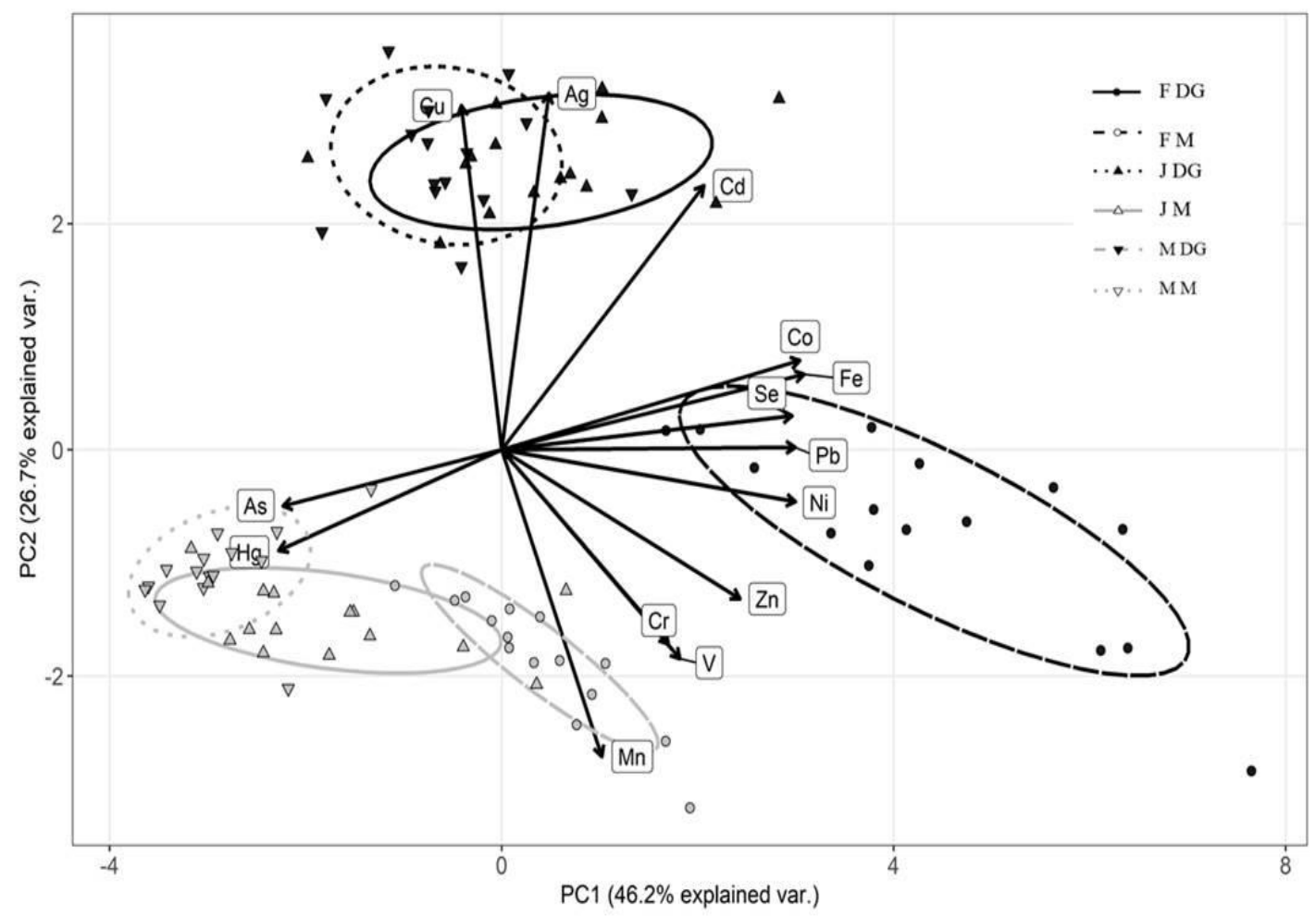

Figure 2. Principal component analysis (PCA) presenting the trace element concentrations in the digestive gland (a) and the mantle tissue. (b) Element loadings along Principle component (PC) 1 and $\mathrm{PC} 2$ are represented by arrows. Abbreviations are the following: female digestive gland (F $\mathrm{DG})$, female mantle (F M), juvenile digestive gland ( $\mathrm{J} \mathrm{DG}$ ), juvenile mantle (J M), male digestive gland (M DG) and male mantle (M M). Ellipses indicate the $95 \%$ confidence interval around tissue/maturity stage groupings. 


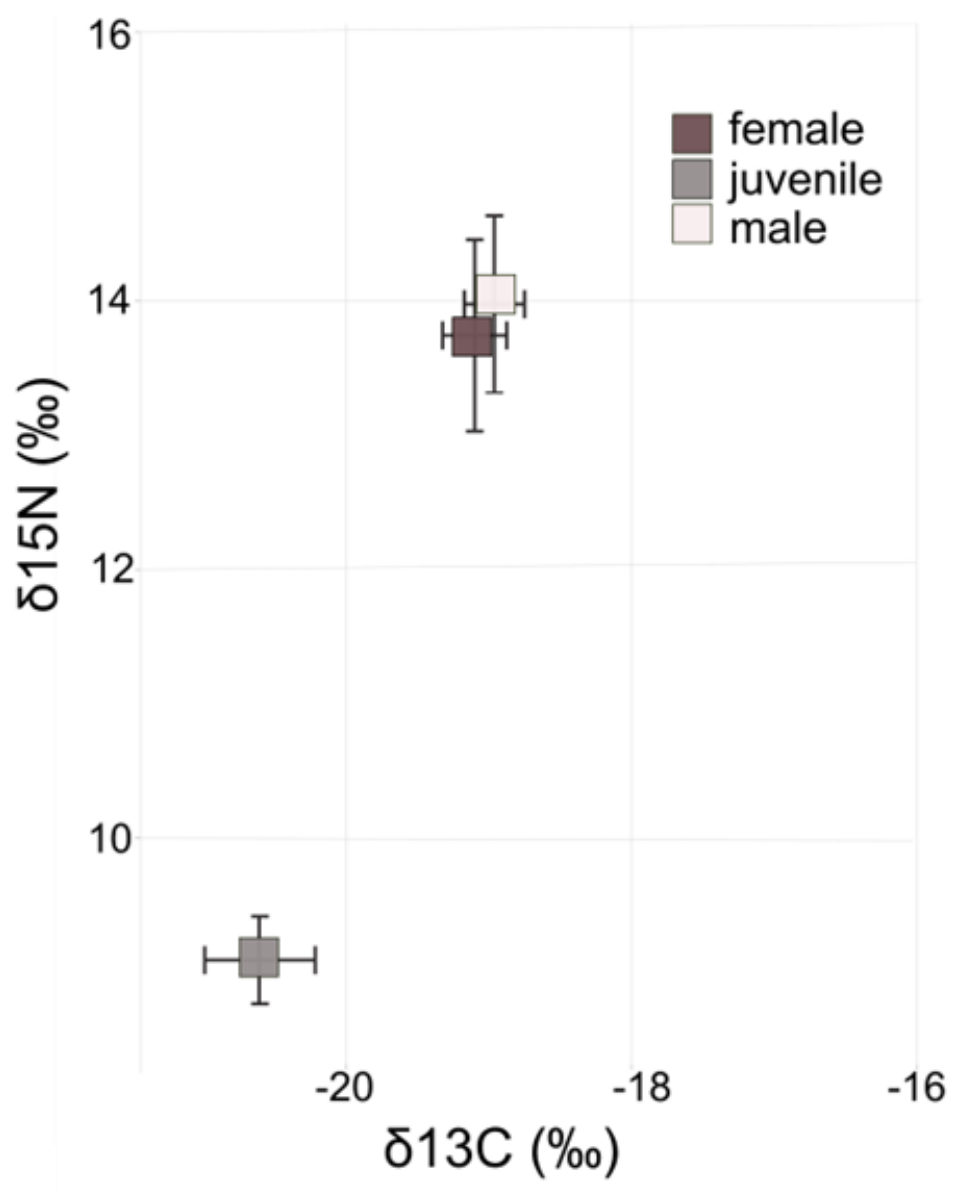

Figure 3. Relationship between $\mathrm{Hg}$ concentrations $\left(\mu \mathrm{g} \cdot \mathrm{g}^{-1} \mathrm{dw}\right)$ and the molar ratio of $\mathrm{Hg}: \mathrm{Se}$ in (a) digestive gland $\left(\mathrm{y}=-0.002+0.19 \mathrm{x}, R^{2}=0.58, p<0.001\right)$ and $(\mathrm{b})$ mantle tissue $\left(\mathrm{y}=-0.002+0.24 \mathrm{x}, R^{2}=\right.$ $0.95, p<0.001)$ of female $(\mathrm{F})$, male $(\mathrm{M})$ and juvenile $(\mathrm{J})$. 


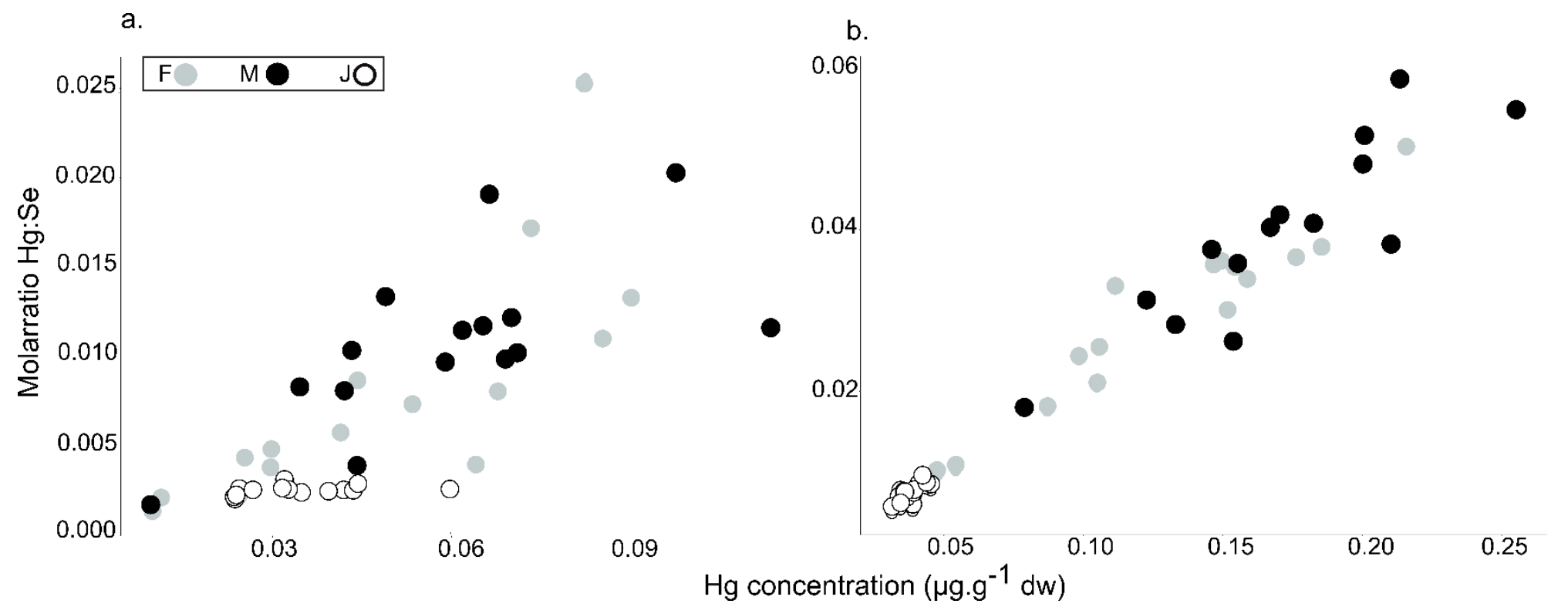

Figure 4. Carbon $\left(\delta^{13} \mathrm{C}\right)$ and nitrogen $\left(\delta^{15} \mathrm{~N}\right)$ stable isotope values $(\%)$ in female, male and juvenile specimen. 
Table 1. Summary of specimen data and trace elemental concentrations for Gonatus fabricii for females $(n=15)$, males $(n=15)$ and juveniles $(n=15)$. Specimen size is presented as dorsal mantle length (DML), muscle stable isotope $\delta^{13} \mathrm{C}$ and $\delta^{15} \mathrm{~N}$ values (reported as \%o), and trace element concentrations (minimum, mean, and maximum) for digestive gland and mantle tissue $\left(\mu \mathrm{g} . \mathrm{g}^{-1} \mathrm{dw}\right)$ Gonatus fabricii specimens.

\begin{tabular}{|c|c|c|c|c|c|c|c|c|c|}
\hline & $\begin{array}{l}\text { Female } \\
\text { Mean }\end{array}$ & Min & Max & $\begin{array}{l}\text { Male } \\
\text { Mean }\end{array}$ & Min & Max & $\begin{array}{l}\text { Juvenile } \\
\text { Mean }\end{array}$ & Min & $\operatorname{Max}$ \\
\hline DML & 12.80 & 7.60 & 19.30 & 17.14 & 9.00 & 27.40 & 4.06 & 3.00 & 5.60 \\
\hline$\delta^{13} \mathrm{C}$ & -19.10 & -19.53 & -18.77 & -18.96 & -19.35 & -18.72 & -20.60 & -21.10 & -19.98 \\
\hline$\delta^{15} \mathrm{~N}$ & 13.74 & 12.75 & 15.15 & 13.98 & 12.64 & 15.12 & 9.09 & 8.59 & 9.64 \\
\hline \multicolumn{10}{|c|}{ Digestive gland } \\
\hline $\mathrm{Ag}$ & 1.20 & 0.44 & 2.23 & 1.03 & 0.45 & 1.83 & 0.22 & 0.14 & 0.44 \\
\hline As & 10.18 & 4.49 & 19.84 & 10.25 & 4.11 & 19.42 & 6.68 & 5.29 & 8.01 \\
\hline $\mathrm{Cd}$ & 31.57 & 5.86 & 63.14 & 31.79 & 4.36 & 58.18 & 41.60 & 25.80 & 62.32 \\
\hline Co & 0.17 & 0.08 & 0.29 & 0.12 & 0.05 & 0.18 & 0.29 & 0.13 & 0.63 \\
\hline $\mathrm{Cr}$ & 0.10 & 0.09 & 0.10 & 0.12 & 0.09 & 0.41 & 1.68 & 0.10 & 11.56 \\
\hline $\mathrm{Cu}$ & 124 & 72.7 & 192 & 138 & 67.6 & 223 & 14.1 & 7.66 & 50.0 \\
\hline $\mathrm{Fe}$ & 57.5 & 22.4 & 136 & 42.8 & 20.1 & 92.4 & 207 & 99.5 & 320 \\
\hline $\mathrm{Hg}$ & 0.05 & 0.01 & 0.09 & 0.06 & 0.01 & 0.11 & 0.04 & 0.02 & 0.06 \\
\hline Mn & 1.01 & 0.82 & 1.29 & 0.85 & 0.51 & 1.21 & 2.45 & 1.18 & 5.45 \\
\hline $\mathrm{Ni}$ & 1.16 & 0.48 & 2.06 & 0.86 & 0.26 & 1.78 & 4.49 & 1.24 & 19.21 \\
\hline $\mathrm{Pb}$ & 0.08 & 0.03 & 0.15 & 0.05 & 0.03 & 0.12 & 0.22 & 0.09 & 0.37 \\
\hline $\mathrm{Se}$ & 2.96 & 1.27 & 6.54 & 2.36 & 1.36 & 4.58 & 5.75 & 3.88 & 9.55 \\
\hline $\mathrm{Zn}$ & 74.0 & 23.0 & 140 & 56.5 & 29.6 & 131 & 136 & 89.8 & 181 \\
\hline \multicolumn{10}{|c|}{ Mantle tissue } \\
\hline $\mathrm{Ag}$ & 0.09 & 0.01 & 0.19 & 0.08 & 0.02 & 0.26 & 0.03 & 0.01 & 0.05 \\
\hline As & 22.31 & 11.65 & 51.07 & 26.30 & 11.30 & 35.39 & 6.06 & 5.57 & 6.81 \\
\hline Co & 0.04 & 0.02 & 0.12 & 0.03 & 0.02 & 0.07 & 0.06 & 0.03 & 0.11 \\
\hline $\mathrm{Cr}$ & 0.32 & 0.10 & 1.84 & 0.28 & 0.10 & 1.53 & 0.99 & 0.20 & 2.43 \\
\hline $\mathrm{Cu}$ & 26.3 & 10.5 & 54.5 & 18.8 & 10.1 & 37.9 & 11.5 & 8.09 & 15.2 \\
\hline $\mathrm{Fe}$ & 18.7 & 8.67 & 42.1 & 9.63 & 4.20 & 13.2 & 48.3 & 18.9 & 163 \\
\hline $\mathrm{Hg}$ & 0.13 & 0.05 & 0.22 & 0.16 & 0.04 & 0.26 & 0.04 & 0.03 & 0.05 \\
\hline $\mathrm{Mn}$ & 2.50 & 1.33 & 3.51 & 1.63 & 1.37 & 2.03 & 1.83 & 1.49 & 2.08 \\
\hline $\mathrm{Ni}$ & 0.81 & 0.27 & 3.20 & 0.49 & 0.26 & 1.45 & 1.15 & 0.41 & 2.46 \\
\hline $\mathrm{Pb}$ & 0.03 & 0.01 & 0.06 & 0.02 & 0.01 & 0.05 & 0.06 & 0.03 & 0.16 \\
\hline $\mathrm{Se}$ & 1.80 & 1.34 & 2.09 & 1.78 & 1.43 & 2.35 & 2.23 & 1.87 & 2.92 \\
\hline $\mathrm{Zn}$ & 90.6 & 41.6 & 131 & 54.0 & 44.4 & 65.3 & 91.7 & 80.1 & 107 \\
\hline
\end{tabular}


Table 2. Analysis of covariance (ANCOVA) for the linear models fitted to the trace element concentration in the digestive gland and muscle tissue. Explanatory variables are as follows: dorsal mantle length (DML), $\delta^{13} \mathrm{C}$ and $\delta^{15} \mathrm{~N}$ values (\%o), and sex. Mantle tissue concentrations for $\mathrm{Cd}$ were excluded due to diffusion of the digestive gland concentrations to the mantle tissue during sample storage. Df represents the degrees of freedom. Asterisks show the level of significance: * $\mathrm{p}<0.05, * * \mathrm{p}<0.01, * * * \mathrm{p}<0.001$.

\begin{tabular}{|c|c|c|c|c|c|c|c|c|c|c|c|c|}
\hline & Df & $\begin{array}{l}\text { Sum of } \\
\text { squares }\end{array}$ & $\begin{array}{l}\text { Mean } \\
\text { square }\end{array}$ & F-value & Significe & nce & Df & $\begin{array}{l}\text { Sum of } \\
\text { squares }\end{array}$ & $\begin{array}{l}\text { Mean } \\
\text { square }\end{array}$ & F-value & \multicolumn{2}{|c|}{ Significance } \\
\hline \multicolumn{7}{|c|}{ Digestive gland } & \multicolumn{6}{|c|}{ Mantle } \\
\hline \multicolumn{13}{|c|}{ Ag } \\
\hline DML & 1 & 4.20 & 4.20 & 63.34 & $<0.001$ & $* * *$ & 1 & 0.40 & 0.40 & 2.28 & 0.14 & \\
\hline$\delta^{15} \mathrm{~N}$ & 1 & 3.89 & 3.89 & 58.62 & $<0.001$ & $* * *$ & 1 & 3.32 & 3.32 & 18.85 & $<0.001$ & $* * *$ \\
\hline Sex & 2 & 0.14 & 0.07 & 1.06 & 0.35 & & 2 & 0.19 & 0.10 & 0.55 & 0.58 & \\
\hline$\delta^{13} \mathrm{C}$ & 1 & 0.18 & 0.18 & 2.77 & 0.10 & & 1 & 0.23 & 0.23 & 1.29 & 0.26 & \\
\hline Residuals & 39 & 2.59 & 0.07 & & & & 39 & 6.86 & 0.18 & & & \\
\hline \multicolumn{13}{|c|}{ As } \\
\hline DML & 1 & 1.49 & 1.49 & 7.75 & 0.01 & $* *$ & 1 & 7.70 & 7.70 & 202.39 & $<0.001$ & $* * *$ \\
\hline$\delta^{15} \mathrm{~N}$ & 1 & 1.27 & 1.27 & 6.60 & 0.01 & $*$ & 1 & 1.65 & 1.65 & 43.31 & $<0.001$ & $* * *$ \\
\hline Sex & 2 & 0.59 & 0.29 & 1.53 & 0.23 & & 2 & 0.15 & 0.07 & 1.92 & 0.16 & \\
\hline$\delta^{13} \mathrm{C}$ & 1 & 0.17 & 0.17 & 0.87 & 0.36 & & 1 & 0.02 & 0.02 & 0.40 & 0.53 & \\
\hline Residuals & 39 & 7.49 & 0.19 & & & & 39 & 1.48 & 0.04 & & & \\
\hline & & & Cd & & & & & & & & & \\
\hline DML & 1 & 0.00 & 0.00 & 0.01 & 0.93 & & & & & & & \\
\hline$\delta^{15} \mathrm{~N}$ & 1 & 1.18 & 1.18 & 8.42 & 0.01 & $* *$ & & & & & & \\
\hline Sex & 2 & 3.65 & 1.83 & 13.03 & $<0.001$ & $* * *$ & & & & & & \\
\hline$\delta^{13} \mathrm{C}$ & 1 & 0.70 & 0.70 & 5.00 & 0.03 & $*$ & & & & & & \\
\hline Residuals & 39 & 5.47 & 0.14 & & & & & & & & & \\
\hline \multicolumn{13}{|c|}{$\mathrm{Cu}$} \\
\hline DML & 1 & 6.42 & 6.42 & 270.98 & $<0.001$ & $* * *$ & 1 & 0.28 & 0.28 & 2.70 & 0.11 & \\
\hline$\delta^{15} \mathrm{~N}$ & 1 & 3.26 & 3.26 & 137.56 & $<0.001$ & $* * *$ & 1 & 6.02 & 6.02 & 57.46 & 0.00 & $* * *$ \\
\hline Sex & 2 & 0.35 & 0.18 & 7.44 & 0.002 & $* *$ & 2 & 0.56 & 0.28 & 2.67 & 0.08 & . \\
\hline$\delta^{13} \mathrm{C}$ & 1 & 0.05 & 0.05 & 2.01 & 0.16 & & 1 & 0.06 & 0.06 & 0.56 & 0.46 & \\
\hline Residuals & 39 & 0.92 & 0.02 & & & & 39 & 4.08 & 0.10 & & & \\
\hline \multicolumn{13}{|c|}{ Hg } \\
\hline DML & 1 & 1.29 & 1.29 & 6.57 & 0.01 & $*$ & 1 & 7.20 & 7.20 & 220.47 & $<0.001$ & $* * *$ \\
\hline$\delta^{15} \mathrm{~N}$ & 1 & 0.94 & 0.94 & 4.80 & 0.03 & $*$ & 1 & 1.53 & 1.53 & 46.89 & $<0.001$ & $* * *$ \\
\hline Sex & 2 & 0.84 & 0.42 & 2.14 & 0.13 & & 2 & 0.89 & 0.45 & 13.65 & $<0.001$ & $* * *$ \\
\hline$\delta^{13} \mathrm{C}$ & 1 & 0.29 & 0.29 & 1.47 & 0.23 & & 1 & 0.10 & 0.10 & 3.01 & 0.09 & . \\
\hline Residuals & 39 & 7.65 & 0.20 & & & & 39 & 1.27 & 0.03 & & & \\
\hline \multicolumn{13}{|c|}{$\mathbf{P b}$} \\
\hline DML & 1 & 5.15 & 5.15 & 84.97 & $<0.001$ & $* * *$ & 1 & 4.78 & 4.78 & 41.24 & $<0.001$ & $* * *$ \\
\hline$\delta^{15} \mathrm{~N}$ & 1 & 1.57 & 1.57 & 25.83 & $<0.001$ & $* * *$ & 1 & 0.19 & 0.19 & 1.66 & 0.21 & \\
\hline Sex & 2 & 0.20 & 0.10 & 1.65 & 0.21 & & 2 & 0.14 & 0.07 & 0.61 & 0.55 & \\
\hline$\delta^{13} \mathrm{C}$ & 1 & 1.71 & 1.71 & 28.27 & 0.00 & $* * *$ & 1 & 1.37 & 1.37 & 11.83 & 0.001 & $* *$ \\
\hline Residuals & 39 & 2.37 & 0.06 & & & & 39 & 4.52 & 0.12 & & & \\
\hline \multicolumn{13}{|c|}{$\mathbf{Z n}$} \\
\hline DML & 1 & 4.18 & 4.18 & 42.66 & $<0.001$ & $* * *$ & 1 & 3.83 & 3.83 & 36.55 & $<0.001$ & $* * *$ \\
\hline$\delta^{15} \mathrm{~N}$ & 1 & 1.80 & 1.80 & 18.40 & $<0.001$ & $* * *$ & 1 & 0.01 & 0.01 & 0.09 & 0.77 & \\
\hline Sex & 2 & 0.65 & 0.32 & 3.30 & 0.05 & $*$ & 2 & 2.94 & 1.47 & 14.04 & $<0.001$ & $* * *$ \\
\hline$\delta^{13} \mathrm{C}$ & 1 & 0.54 & 0.54 & 5.49 & 0.02 & $*$ & 1 & 0.12 & 0.12 & 1.19 & 0.28 & \\
\hline Residuals & 39 & 3.83 & 0.10 & & & & 39 & 4.09 & 0.10 & & & \\
\hline
\end{tabular}


Table 3. Comparison of digestive gland $\mathrm{Cd}$ concentrations reported for various squid species. All concentrations are indicated as $\mu \mathrm{g} \cdot \mathrm{g}^{-1} \mathrm{dw}$.

\begin{tabular}{|c|c|c|c|}
\hline Species & Mean \pm SD & Sampling Location & Study \\
\hline Gonatus fabricii & $35 \pm 15$ & $\begin{array}{l}\text { Disko Bay, } \\
\text { Greenland }\end{array}$ & This study \\
\hline Architeuthis dux & $65.8 \pm 43.1$ & Bay of Biscay & Bustamante et al. 2008 \\
\hline Illex argentinus & $1003 \pm 566$ & $\begin{array}{l}\text { Central South Brazil } \\
\text { Bight }\end{array}$ & Dorneles et al., 2007* \\
\hline Illex argentinus & 92.5 & Argentina & Falandysz, 1988 \\
\hline Illex argentinus & $5.1 \pm 1.5$ & Patagonia & Gerpe et al., 2000 \\
\hline Illex argentinus & $145 \pm 65$ & Argentina & Kurihara et al., 1993 \\
\hline Illex coindetii & $0.12 \pm 0.05$ & Adriatic Sea & $\begin{array}{l}\text { Storelli and } \\
\text { Marcotrigiano, 1999* }\end{array}$ \\
\hline Illex coindetii & $15 \pm 5$ & Bay of Biscay & Bustamante et al. 2002 \\
\hline Nototodarus gouldi & $50 \pm 25$ & $\begin{array}{l}\text { Bass Strait, } \\
\text { Australia }\end{array}$ & Smith et al., 1984 \\
\hline Nototodarus gouldi & $33 \pm 30$ & $\begin{array}{l}\text { Port Phillip Bay, } \\
\text { Australia }\end{array}$ & Finger and Smith, 1987 \\
\hline Nototodarus sloanii & $111 \pm 95$ & $\begin{array}{l}\text { Chatham Rise, New } \\
\text { Zealand }\end{array}$ & Lischka et al., 2019 \\
\hline $\begin{array}{l}\text { Ommastrephes } \\
\text { bartramii }\end{array}$ & $827 \pm 369$ & Sea of Japan & Kurihara et al., 1993 \\
\hline $\begin{array}{l}\text { Ommastrephes } \\
\text { bartramii }\end{array}$ & $287 \pm 194$ & Southern California & Martin and Flegal, 1975 \\
\hline $\begin{array}{l}\text { Sthenoteuthis } \\
\text { oualaniensis }\end{array}$ & 198 & Japanese Sea & Ichihashi et al., 2001* \\
\hline Sthenoteuthis pteropus & $748 \pm 279$ & $\begin{array}{l}\text { Eastern Tropical } \\
\text { Atlantic }\end{array}$ & Lischka et al., 2018 \\
\hline Todarodes filippovae & $246 \pm 187$ & Indian Ocean & Kojadinovic et al., 2011 \\
\hline Todarodes filippovae & $98.5 \pm 67.2$ & Tasmania & Kojadinovic et al., 2011 \\
\hline Todarodes pacificus & 16.7 & Sea of Japan & Ishizaki et al., 1970 \\
\hline Todarodes sagittatus & $85 \pm 37$ & Bay of Biscay & Bustamante et al., 2002 \\
\hline Todarodes sagittatus & $18 \pm 12$ & Bay of Biscay & Chouvelon et al., 2011 \\
\hline
\end{tabular}


Table 4. Comparison of digestive gland Ag concentrations reported for various squid species. All concentrations are indicated as $\mu \mathrm{g} \cdot \mathrm{g}^{-1} \mathrm{dw}$.

\begin{tabular}{|c|c|c|c|}
\hline Species & Mean \pm SD & Sampling Location & Study \\
\hline Gonatus fabricii & $0.82 \pm 0.55$ & $\begin{array}{l}\text { Disko Bay, } \\
\text { Greenland }\end{array}$ & This study \\
\hline Architeuthis dux & $1.90 \pm 0.47$ & Bay of Biscay & Bustamante et al., 2008 \\
\hline Nototodarus gouldi & $3.3 \pm 1.4$ & $\begin{array}{l}\text { Bass Strait, } \\
\text { Australia }\end{array}$ & Smith et al., 1984 \\
\hline Ommastrephes batramii & $12.1 \pm 8.6$ & Southern California & Martin and Flegal, 1975 \\
\hline Sthenoteuthis oualaniensis & $24.1 \pm 10.9$ & Southern California & Martin and Flegal, 1975 \\
\hline Sthenoteuthis pteropus & $9.86 \pm 3.44$ & $\begin{array}{l}\text { Eastern Tropical } \\
\text { Atlantic }\end{array}$ & Lischka et al., 2018 \\
\hline Todarodes filippovae & $3.04 \pm 1.55$ & Tasmania & Kojadinovic et al. 2011 \\
\hline Todarodes filippovae & $3.40 \pm 1.60$ & Indian Ocean & Kojadinovic et al. 2011 \\
\hline Todarodes pacificus & $7 * \pm \mathrm{NA}$ & Sea of Japan & Ichihashi et al., 2001 \\
\hline
\end{tabular}

*concentrations have been converted from wet weight 


\section{Supplementary information}

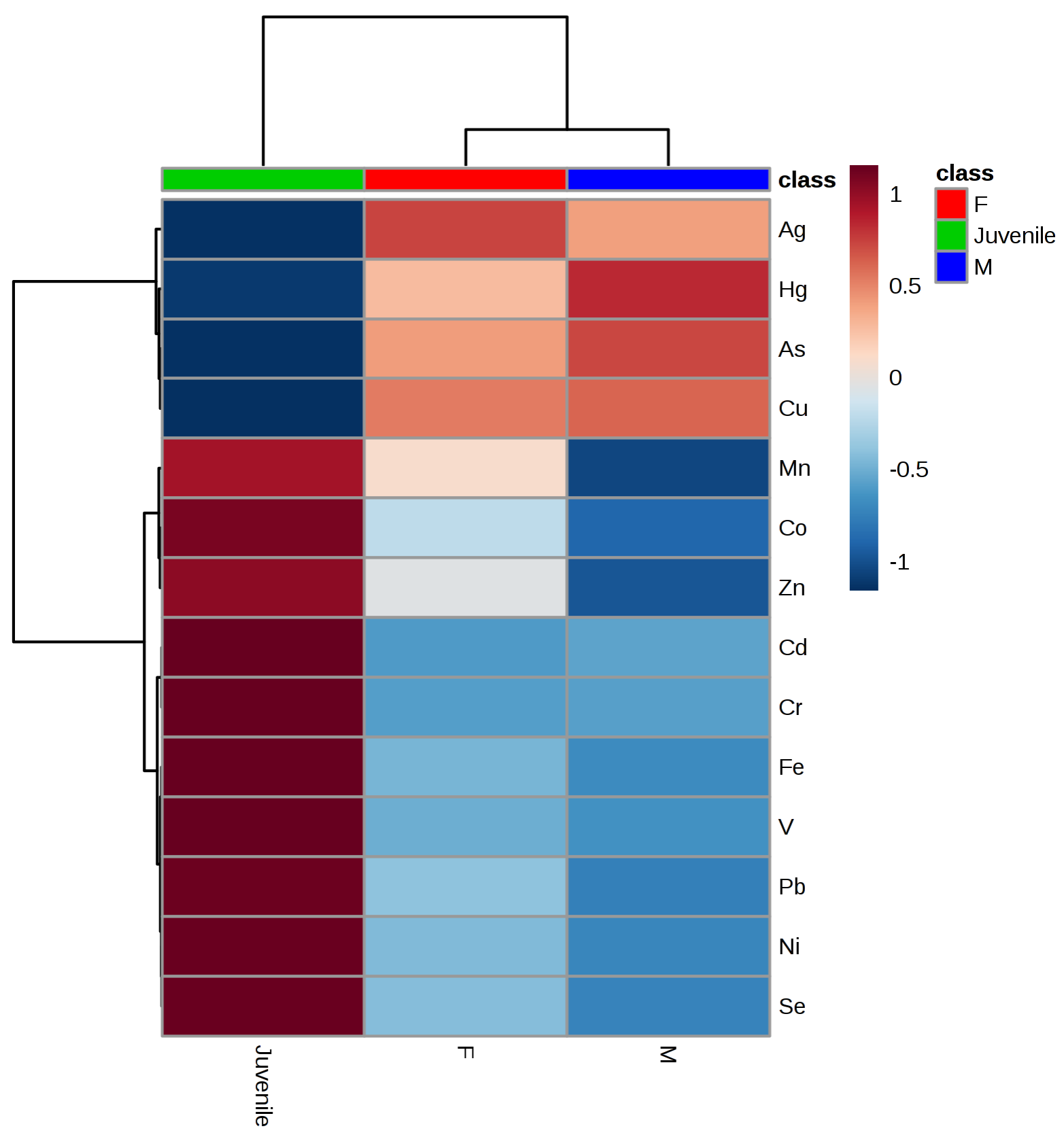

Figure S1. Heatmap of the auto-scaled trace element concentrations in the digestive gland of the three different groups analysed herein (female, male, and juvenile). Darker colours symbolize a stronger correlation. Hierarchical clustering is indicated by brackets. 